\title{
Current methods for diagnosis of human coronaviruses: pros and cons
}

\author{
Mercy R Benzigar ${ }^{1,2} \cdot$ Ripon Bhattacharjee ${ }^{1,2} \cdot$ Mahroo Baharfar $^{1,2} \cdot$ Guozhen Liu $^{1,2}$
}

Received: 3 July 2020 / Revised: 14 October 2020 / Accepted: 4 November 2020 / Published online: 20 November 2020

(C) Springer-Verlag GmbH Germany, part of Springer Nature 2020

\begin{abstract}
The current global fight against coronavirus disease (COVID-19) to flatten the transmission curve is put forth by the World Health Organization (WHO) as there is no immediate diagnosis or cure for COVID-19 so far. In order to stop the spread, researchers worldwide are working around the clock aiming to develop reliable tools for early diagnosis of severe acute respiratory syndrome (SARS-CoV-2) understanding the infection path and mechanisms. Currently, nucleic acid-based molecular diagnosis (real-time reverse transcription polymerase chain reaction (RT-PCR) test) is considered the gold standard for early diagnosis of SARS-CoV-2. Antibody-based serology detection is ineffective for the purpose of early diagnosis, but a potential tool for serosurveys, providing people with immune certificates for clearance from COVID-19 infection. Meanwhile, there are various blooming methods developed these days. In this review, we summarise different types of coronavirus discovered which can be transmitted between human beings. Methods used for diagnosis of the discovered human coronavirus (SARS, MERS, COVID-19) including nucleic acid detection, gene sequencing, antibody detection, antigen detection, and clinical diagnosis are presented. Their merits, demerits and prospects are discussed which can help the researchers to develop new generation of advanced diagnostic tools for accurate and effective control of human coronavirus transmission in the communities and hospitals.
\end{abstract}

Keywords Human coronaviruses $\cdot$ COVID-19 $\cdot$ Biosensors $\cdot$ Serology detection $\cdot$ Molecular diagnostics

\section{Introduction}

Infectious biological outbreaks and human health risks began since 1965 when the virus B814 was identified in the human respiratory tract. Since then, the OC43 and 229E of human strains were widely studied, when there was $229 \mathrm{E}$ outbreak in children's health $[1,2]$. While around this time, many of the other coronavirus species of animal origin, recently the existence of coronavirus in bats and birds, were growing rapidly $[3,4]$. This led to the classification of virus into three broad groups based on their genomic sequences, namely group 1 (229E and their derivatives), group 2 (OC43), and group 3 (airborne and bronchitis viruses) [5-12]. The acute respiratory

Guozhen Liu

guozhen.liu@unsw.edu.au

1 Graduate School of Biomedical Engineering, University of New South Wales, Sydney, NSW 2052, Australia

2 Australian Centre for NanoMedicine, University of New South Wales, Sydney, NSW 2052, Australia syndrome outbreak in southern China in 2002, and wide spreading in 29 countries, was caused by the coronavirus and is called severe acute respiratory syndrome (SARSCoV-1) $[13,14]$. Following this was another type of coronavirus that caused Middle East respiratory syndrome (MERS$\mathrm{CoV}$ ) in 2012 at the Middle East. All three outbreaks are due to the coronavirus infection although the specific sequence of coronaviruses is different. In 2019, a new coronavirus was identified as the cause of a disease outbreak that originated in China, which is now known to be a critical respiratory disease caused by the SARS-CoV-2, termed as coronavirus disease 2019 (COVID-19). In March 2020, the World Health Organization (WHO) declared the COVID-19 outbreak as a pandemic. Currently, the COVID-19 is identified to be caused by the strain of SARS, with more pathogenicity leading the human health risk and losses. This outbreak happened in late 2019 in China, and now the infections are almost widened in most of the countries encircling the universe. As current outbreaks of COVID-19 continue to evolve, COVID-19 has become a serious global health concern because of the possible fatal progression and rapidly growing numbers of new cases causing massive economic loss globally. 
As COVID-19 outbreaks surge worldwide, understanding a crucial epidemiological puzzle (such as what proportion of infected people have mild or no symptoms and might be passing the virus on to others, and what type of people need to be quarantined) is critical. It is an immediate need to improve the detection assays to provide early, rapid, and reliable diagnosis of COVID-19 to stop the spread of COVID-19. There are no accurate diagnosis method or vaccine available for this infection so far, which raises the challenges, and also drives researchers keen on developing, improving, and working on innovative methods for the diagnosis which is expected to help the treatment then. Recently several excellent reviews on the specific diagnosis of COVID-19 [15-17] have been reported. Another review has summarised recent advances in the detection of virus infection in the respiratory tract of humans [18], focusing on molecular diagnosis of virus. Recently, biosensing devices that are designed primarily through applying effective biomarkers and their impact on the detection of respiratory tract viruses have been widely reported, in which the scope of disposable technologies well-suited for cheap and economically viable platforms for creating portable devices was also highlighted [19]. However, the issue of making these technologies practical especially for current contagious infection caused by COVID-19 throws the biggest challenge to the researchers worldwide.

Being different from other recent published reviews, this review summarises different types of coronavirus discovered so far which can be transmitted between human beings. Their structures and effect on human health were compared. Methods used for diagnosis of the discovered fatal human coronaviruses (SARS-CoV-1, MERS-CoV, and SARS-CoV2) including nucleic acid detection, gene sequencing, antibody detection, antigen detection, and clinical methods are presented (Scheme 1). Their merits and demerits and prospects are discussed with the perspectives that could help researchers to develop new generation of advanced diagnostic tools for the accurate diagnosis of COVID-19 and effective control of human coronavirus transmission in the community and hospitals.

\section{Human coronavirus and their structures}

Coronaviruses are enveloped viruses with spikes around its outer structure, containing a constructive single-stranded RNA with full length approximately up to $32 \mathrm{~kb}$ [20] acting as the mRNA during the replicase polyprotein translations. They belong to the family of Nidovirales, with spherical structure ranging approximately $125 \mathrm{~nm}$ in diameter [21, 22]. Coronaviruses are frequently identified in respiratory tract fluids. SARS-CoV-2 is observed to be present in human blood, saliva, and even stool [23]. Four main groups of coronavirus subdivided into alpha, beta, gamma, and delta types

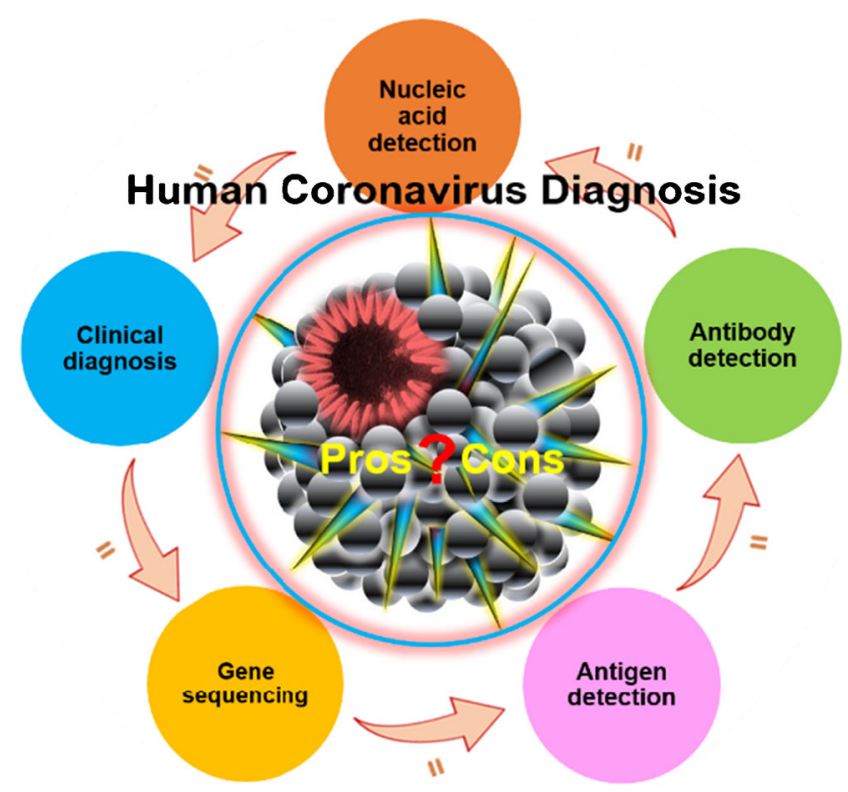

Scheme 1 The schematics of the content of this review

have been identified so far. Among them, the common human coronaviruses are 229E, NL63, OC43, HKU1, MERS-CoV, and SARS-CoV. 229E and NL63 genera belong to alpha coronavirus genera and delta coronaviruses include MERSCoV, SARS-CoV, OC43, and HKU1 genera [15]. The coronaviruses that have caused huge impact or lethal in human beings are MERS-CoV, SARS-CoV, and SARS-CoV-2 which are compared in Table 1. The coronaviral genome encodes four major structural proteins: the spike (S) protein, nucleocapsid $(\mathrm{N})$ protein, membrane $(\mathrm{M})$ protein, and the envelope (E) protein, all of which are required to produce a structurally complete viral particle [30]. Individually, each protein primarily plays a role in the structure of the virus particle, but they are also involved in other aspects of the replication cycle.

The antigen commonly present in the virus is the S glycoprotein, which is referred to the spikes of the virus with the ability to bind with the receptor and fuse with the membranes of the host. This viral fusion protein functions by two ways: (1) it uses their primary subunit protein $\mathrm{S} 1$ that acts to bind the receptor; (2) the subunit S2 aids in the fusion by targeting the cell membrane of the receptor. After targeting, the virus undergoes conformational changes triggered by the proteolytic enzymes and inserts the peptide into the cell membrane. Finally, the delivery of the viral genome in the cytoplasm occurs supported by irreversible refolding of the fusion protein subunit $\mathrm{S} 2$, mediated by the angiotensin-converting enzyme 2 (ACE2). A recent study suggests that SARS-CoV-2 may exploit cytokine interferon-driven upregulation of ACE2, a key tissue-protective mediator during lung injury, to enhance infection [31]. It is known that $\mathrm{S}$ protein also interacts with specific antibodies against $\mathrm{S}$ protein; the reason behind is the virus has a spectrum of evolution in antigenic variations 
Table 1 Comparison of three fatal human coronaviruses

\begin{tabular}{|c|c|c|c|c|c|c|c|c|}
\hline \multirow[t]{2}{*}{ Corona virus } & \multicolumn{4}{|l|}{ Structure } & \multirow[t]{2}{*}{ Body fluids found } & \multirow[t]{2}{*}{ Case fatality rate } & \multirow[t]{2}{*}{ Velocity } & \multirow[t]{2}{*}{ References } \\
\hline & $\mathrm{N}$ protein & $\mathrm{S}$ protein & E protein & M protein & & & & \\
\hline SARS-CoV & Yes Major & Yes & Yes & Yes & Respiratory tract fluids, blood, saliva & $11 \%$ & 903 days & {$[24,25]$} \\
\hline MERS-CoV & Yes & Yes & No & No & Respiratory tract fluids, blood, saliva & $37.1 \%$ & 130 days & {$[26,27]$} \\
\hline SARS-CoV-2 & Yes & Yes & Yes & Yes & $\begin{array}{l}\text { Respiratory tract fluids, blood, saliva, } \\
\text { stool, breast milk etc. }\end{array}$ & $4.44 \%$ estimated & 48 days & {$[28,29]$} \\
\hline
\end{tabular}

time to time. Also, the $\mathrm{S}$ protein in the cell membrane expresses the cell to cell fusion forming multi-nucleated cells allowing the multiplication of the antibodies, which at the same time easily enhances the activity of cross-neutralisation [32-34]. The N protein is a viral structural protein functioning as a replication unit to localise the replication and transcription complexes. It aids to form the RNA to helical nucleocapsid structure and helps in the viral RNA synthesis constituting only to the nucleocapsid. The $\mathrm{N}$ protein composes of two domains, namely $\mathrm{N}$-terminal and $\mathrm{C}$-terminal, both using two different mechanisms to bind the RNA, but at the same time the contribution of both is required for the optimal binding. This results in the type I interferon suppression and potentially degrades the double-stranded RNA during the replication of the virus [35-40]. M protein contributes to the major density of the viral structure that defines its shape of the viral envelop. However, it cannot function alone to lead the viral cycle but also needs to interact with the other structural proteins of the virus. The $\mathrm{M}$ protein combines initially with the $\mathrm{N}$ protein to establish the viral nucleocapsid. Then, it interacts with S protein for the assembly of virions in the retention and accumulation in Golgi complexes. Later, it combines with the E protein for the multiplication and releasing the virus-like particles in the host cells [41-43]. E protein is the smallest protein present in the membrane helping in forming the budding sites. Secondly, it combines with the $M$ protein engaging in the production of virus-like particles. Following this, it participates in the viral assembly then in releasing the virus and taking part in the mechanism of pathogenesis as well [44-47]. However, up to date, the particular role of E protein is not yet found. E protein helps the M protein to proceed the membrane curvature, although it is found that the $M$ protein itself can do the same revealed through microscopic studies. The major difference between the current COVID-19 with that of the similar SARS-CoV and MERS-CoV is that the amino acids of COVID-19 virus are varied specifically in the polyprotein regions and in the $\mathrm{S}$ glycoprotein.

Coronaviruses are contagious especially in the case of SARS-CoV-2 causing the COVID-19 pandemic. It is estimated that around $20-80 \%$ of all COVID-19 infections are covert cases showing limited to no symptoms, which has caused huge risk for virus transmission [48]. The transmission and infection of SARS-CoV-2 are through three main ways, such as cause, routes, and target's immune. As such, the current studies demonstrate that the pangolins and the snakes could be the intermediate host for this virus [49, 50]. However, human to human path of transport is currently considered the major sources of human mucus, saliva, faeces, or contacts. Studies on human breast milk for the search on existence of SARS-CoV-2 virus by Grob et al. [29] traced the presence of viral RNA. But their studies remain unclear about if the breast milk would be a path of viral transmission. Although the breast milk was also examined for the SARS and the influen$\mathrm{za}$, the test for SARS and mode of transmission still remain unclear. This is because, even though the maternal showed positive towards SARS-CoV, the breast feeding without any protective measures showed negative COVID result on the infant. The same was denoted for the influenza virus detection but the authors ensure the distancing between the mother and infant as the impact of viral infection is not clear through investigation [51]. Similar to these reports, the studies by Lackey et al. also did not trace the presence of SARS-CoV-2 in infants spread through breast milk but the vertical transmission was discussed [52]. While the constant presence of SARS-CoV-2 is found persistent in the human saliva that was extracted through the RT-PCR for the nucleic acid detection [53]. The symptom of SARS-CoV-2-infected patients was not very different from the SARS-CoV-1 and MERS$\mathrm{CoV}$ but the fatal rate and frequency of infection are very high compared to the remaining two (Table 1).

It is also shocking to notice that the renal damages in patients had happened due to the anti-viral drugs [54]. Apparently, many patients exhibited high C-reactive protein, increased D-dimer, high inflammatory factors, creatinine levels, and many more. The COVID-19 is also found to be associated with and contribute to serious and critical diseases in the kidney, liver, and lungs, totally attacking the immune system of the patient [55]. Surprisingly, the spread of SARSCoV-2 was also found in the wastewater which is reported by Ahmed et al. [56]. This could cause wide spreading to the community as the wastewater treatment is a heavy duty and progressive methods are needed to detect and eliminate the coronavirus from the untreated environment. Thus, sensitive and accurate diagnosis of coronavirus especially for the 
current COVID-19 is extremely crucial in controlling the outbreak in the community and hospitals [57].

\section{Methods for diagnosis of human coronaviruses}

Development of the accurate and rapid diagnostic testing is essential to control virus outbreak. These tests must be sensitive, reliable, and scalable. Medical screening of coronavirus depends on the past infections, clinical demonstration, and nautical tests including the screening of viral nucleic acid by a swab test, CT scan, immune identification technology (IgM/ IgG antibody tests), and blood culture [15]. Due to the complexity of coronavirus, it is recommended to use the combined technologies to make a precise diagnosis. Overall, while nucleic acid testing is appropriate for the detection of the coronavirus since, it helps in the critical episodes. To improve the detection pathways, employing both the gene detections and the serological methods could be a prominent strategy at the situation to improve the accuracy of the coronavirus diagnosis. The following sections will discuss the current methods for diagnosis of human coronavirus.

\section{Nucleic acid detection-based methods}

The nucleic acid detection is a genetic molecular diagnostic technique that applies to detect the specific nuclear sequence through which the specific species, organism, or genera can be identified. To diagnose such organisms by targeting the nucleic acid sequences, synthetic amplification method is required. As such, the nucleic acid detection methods are master on amplification using the primers and probes to detect the specific organism for specific diseases. But, this only suits for organisms that are already known with their genetic sequences. Lu et al. [21] studied the genome of the current out breaking SARS-CoV-2 collected from nine patients and found the sequence identity between them through homology modelling, also revealing the similarity in the receptor binding sites. Similar kinds of studies were also carried out by Paraskevis et al., revealing $96.3 \%$ genomic similarity with the bat coronavirus [60]. Due to high specificity and sensitivity of molecular diagnosis, currently, the nucleic acid identification has become a primary technique to detect the coronavirus. The assay based on quenching the primer and the probe developing into a RT-RPA to target the SARS-CoV-2 viral RNA was reported by Behrmann et al. [61]. Recently, Shen et al. [62] have published a grant review to address the advantages of nucleic acid detection for coronavirus. Herein, we have classified and compared different nucleic acid detection approaches and highlighted the pros and cons of those methods in virus detection.

\section{RT-PCR}

RT-PCR is considered the 'gold standard' method for detection of human coronaviruses due to being quantitative and specific. A schematic illustration of RT-PCR is given in Fig. 1 (a). Generally, PCR works on enzymatic way that replicates a single gene into multiple copies by separating the two strands of DNA where the gene segment is present. The gene segment is located when it is marked by the primer, and the first sequence is made by the DNA polymerase that assembles each of the segments. Then, it is copied to form multiple copies, which is amplified in minutes [63]. Prior to the intervention of RT-PCR, the broad range PCR which can process the amplification for the complete genera was used for the viral detection [64]. However, it failed for detection of an increasing number of samples due to the limitation in sequencing many numbers of colonies in a single reaction. In 1994, Myint et al. [65] developed the PCR assay for detecting the human OC43 and 229E coronaviruses and predicted that this would be faster and more sensitive than the conventional cell culture and could be used in future as an efficient detection technology. Recently, the ORF1b and the $\mathrm{N}$ regions of the viral genome were detected via with real-time RT-PCR. In this method, the clinical samples were diagnosed finding two positive cases proving viability of technique suitable for samples of human origin [66].

Currently, the research in the real-time RT-PCR is dedicated for improving the sensitivity and facilitating the handling in terms of consumption of cost and time [67]. It has also been widely used as a tool for diagnosing the patients with respiratory tract infection although adverse contaminations during the process of clinical samples are unavoidable. However, the limitations prolonged on clinical samples due to adverse contaminations. To overcome this issue, Elden et al. [68] have developed the multiplex-Taqman-real-time nested PCR assay. In this assay, they first isolated the viral RNA; then, the nested PCR was carried out by deriving the primers and modifying them by removing the $\mathrm{T}$ of the antisense primer, to target the nucleocapsid $(\mathrm{N})$ genome of the virus. Although it was a bit more sensitive assay, the major drawback was still the contamination specially in testing the clinical samples and it was identified that the method is lacking a stable positive control (EPC) causing the problem. After 2 years, the problem was taken into serious importance and engineered to generate a non-infectious RNA from the phage which was applied as an EPC for SARS-CoV [69]. However, the detection limitation per reaction in terms of the number of copies was not met because working around reducing the contamination affected the rapid reductions in the number of copies used in a single reaction. At this moment, scientists have investigated on choosing the appropriate specimen because selecting right source can improve the diagnostic efficiency or in other words, the interruptions from the sample can be minimised 
a

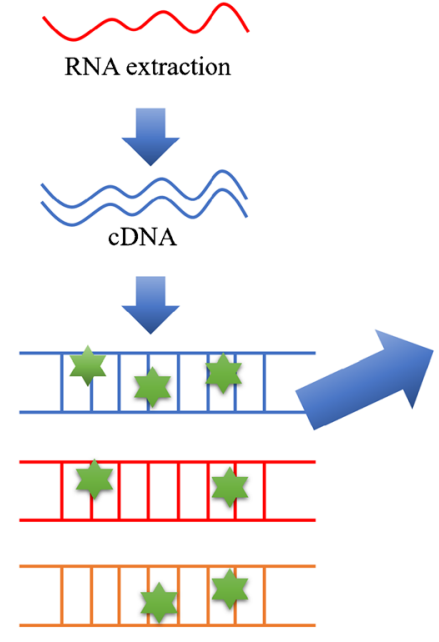

b

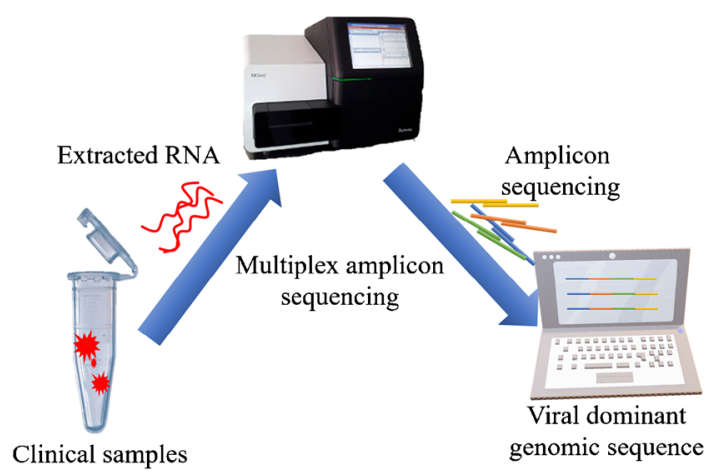

RT-PCR readout

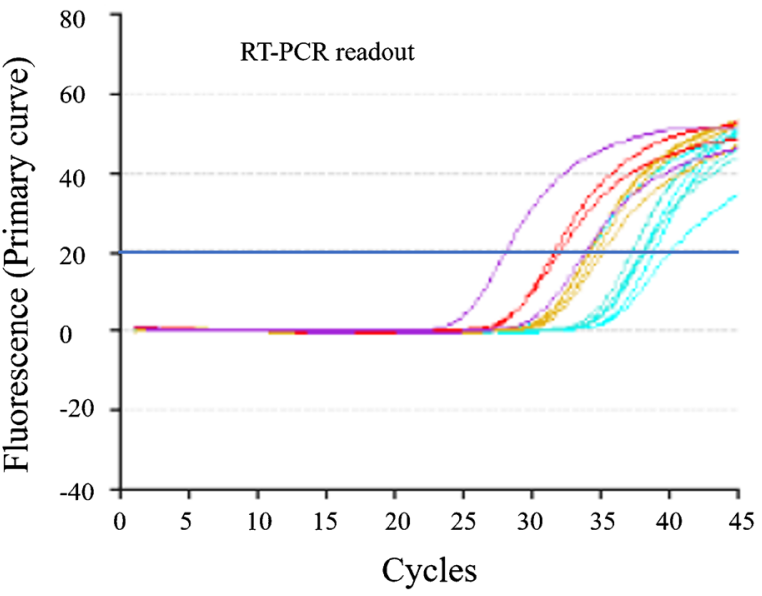

C

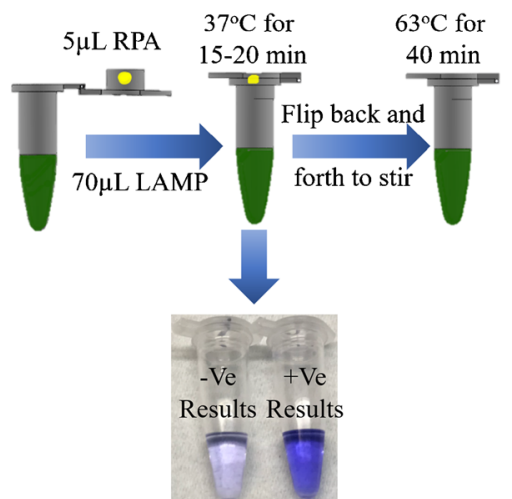

Fig. 1 Schematic representation for the promising techniques generally used to detect SARS-CoV-2: (a) RT-PCR method is carried out from the reverse transcription of viral RNA into cDNA which is then amplified using specific primers. The amplification process is confirmed from the fluorescent signal indicating the total number of copies in target sequence. (b) Whole genomic sequencing is a complete gene sequencing method which is complicated and not helpful for urgent and large-scale detection. Generally, the viral RNA is extracted from the specimen going through multiplex amplicon sequencing to identify the nucleic acid [58]. Redrawn with permission. (c) Combined method of LAMP and COVID-19 PennRAMP: The Penn-RAMP contains two processes of isothermal

by the wise specimen collection. For example, researchers collected swabs from both the throat and sputum separately and then carried out the RT-PCR for the detection of the virus in 52 COVID-19 patients. As a result, the successive rate of detection was higher for the sample collected from the throat swabs revealing $76.9 \%$ efficiency. But, taking the viscosity of the samples into consideration, the sputum is higher in viscosity than the throat swab; thus, in order to achieve easy RNA extraction, pre-treatment of the specimen is inevitable [70].

Nowadays researchers are investigating the line between the type I virus (SARS-CoV-1) and type II virus (SARS$\mathrm{CoV}-2$ ) using RT-PCR because the type II is more virulent in mutating their genomic sequences compared to the type I [71]. But the current SARS-CoV-2 uses the ACE2 receptor to invade the cell membrane similar to that of the SARS-CoV-1 amplification, first the RPA was carried out at $37^{\circ} \mathrm{C}$ at the cap of the tube and then the LAMP at $63{ }^{\circ} \mathrm{C}$ within the tube. The LAMP reaction mixture was added with the LCV dye and the ratio between RPA and LAMP was $1: 9$. This was incubated at $38^{\circ} \mathrm{C}$ for $15-20 \mathrm{~min}$ followed by flipping for through mixing moving towards second time incubation in a thermal cycler for $40 \mathrm{~min}$ at $63{ }^{\circ} \mathrm{C}$. LCV dye helped by producing dark violet signal in the presence of dsDNA and colourless in the absence of dsDNA. This method was found to have high potential as it reduced false negatives [59]. Re-produced, permission has taken under the CC-BYNC-ND 4.0 International license)

which Zhou et al. found that the full-length genome of affected patients had approximately $80 \%$ shared viral genome [72]. In their study, the evaluation on the receptor used for the cell invasion was determined through microscopic studies, where the analysis of the infectivity in HeLa cells was carried out, based on the ACE2 expression, and the determination was visualised. In that study, SARS-COV-2 used the ACE2 proteins as an entry site while it did not do the same on mouse ACE2. While for the SARS-Cov-1, the diagnosis was done within 5 days of infection using RT-PCR. This method is found to be prominent for both SARS-CoV-1 and the MERS virus. Within 2 years of outbreak in the Middle East in 2012, Lu et al. [73] developed the RT-PCR assays to target the $\mathrm{N}$ gene of the MERS-CoV virus. Prior to this, the detection of the $\mathrm{E}$ gene was studied for the detection of the same virus 
but targeting the $\mathrm{N}$ gene which was found to be ahead comparatively [74]. However, all the assays detected 10 copies per reaction and these assays were conducted in serum, stool specimens, and respiratory fluids.

The evaluation in the receptor helped the researchers to study the specific immune reactions and classify the similarity and differences of both species in human and animal. Coming to the impact of the recent RT-PCR, new positive and negative external controls, namely nCoVPC and No Template Control (NTC), have been developed. The nCoVPC is a positive-type external control, and NTC is a negative-type control. The positive-type control has a transcribed RNA so with the N1 and $\mathrm{N} 2$ primers and human RNase $\mathrm{P}$ gene, it can exhibit a positive result. The negative type uses the nuclease-free water in place of RNA. Both the controls in assays should exhibit the threshold line within 40 cycles. However, this information is advised for emergency use only [75]. The Chinese National Institute for Viral Disease Control and Prevention has demonstrated a nucleic acid assay [76]. In this assay, they have used open reading frame $1 \mathrm{ab}$ (region, ORF) as target 1 and the nucleoprotein for the target 2 and this assay is widely distributed in China. Later, the same method with two single steps assay for $\mathrm{N}$ gene and ORF1b was distributed to 30 labs globally by the University of Hong Kong. Likewise, Altona diagnostics in Germany, BGI in Beijing, Novacyt Primer design, and many others have developed the real-time PCR assays worldwide [77].

Even though the RT-PCR allows analysis of the pathogenesis, it has not been proved for its effectiveness in determination and cease of viral invasion in a crowd of patients. Additionally, due to the biological variability that is the levels of mRNA expressed fluctuates in different tissues and inconsistent at different times may cause negative results in clinical diagnosis [78]. The technical variability which is causing the poor data analysis is also one of the major drawbacks of the RT-PCR $[79,80]$. Very recently, a study was carried out by Liu et al. [81], who compared the nucleic acid detection method and the serological method parallelly on 52 severe COVID-19 cases. This was simply done to explore more reliable diagnostic method among the two well-known techniques. Firstly, in the nucleic acid detection method, the RTPCR was applied to quantitatively find the ORF1ab and N genes and the interpretation was done based on obtaining both parallel positive and serially positive ORF1ab/N gene. This RT-PCR test working on the principle of fluorescence indicated $71.2 \%$ positive cases. On the other hand, the serology test based on $\operatorname{IgM}$ and $\operatorname{IgG}$ antibodies working on the principle of chemiluminescence indicated $93.2 \%$ positive cases among the serious patients. In this study, the authors suggest that the serological test may be an applicable supplement like RTPCR method.

To overcome the disadvantages of the RT-PCR, Shiyin et al., in their recent review, suggested that the digital PCR has been demonstrated to increase the sensitivity of detection and suitable for presence of virus at low concentration in samples [82]. Suo et al. [83] have proved that this method provides advantage towards the clinical diagnosis because 33 COVID19 negative patients tested through RT-PCR were found positive when tested at digital PCR method. But this method endures limitation as it is not scalable and lacks practical reliability.

\section{High-throughput gene sequencing}

High-throughput gene sequencing (HTGS) is a high-end sequencing technology that supplies the vital elements on pathogenic complete sequences. HTGS has been applied to facilitate rapid large-scale virus discovery, as well as the detection of unusual or novel viral agents associated with inheritable diseases, cancer, and infectious human diseases. Recently, gene sequencing has helped to identify coronaviruses isolated from patients with COVID-19 in different countries [84-86]. Additionally, by combining diagnostics with sequence analyses, HTGS offers opportunities to enhance public health disease interventions and disease surveillance. A schematic working procedure of genomic sequencing is shown in Fig. 1(b) [58]. Challenges facing current sequencing platforms and their clinical applications are discussed in an excellent review [87]. Although HTGS has demonstrated its significant contribution to disease discovery and interventions, the accurate genome sequencing will still rely on a combination of technologies. In order to increase the coverage across the genome, the multiplex methods of PCR assigned to introduce possibilities to obtain consensus genome sequences directly from samples [88]. Although the approach was potent and convenient for the routine laboratory detections, it has the drawback of possibly providing biased results due to the alignment of reads against a reference sequence. To solve this problem, recently sequencing was done to encompass the genomics of the virus. Since deriving the complete sequence is challenging, the authors concentrated on the dominant genetic part from the clinical samples to trace the function of vulnerability [89]. This robust method was able to carry out sequencing with the relative high size of the genome sequence $(30 \mathrm{~kb})$. Di et al. reported a simple and accurate RNA sequencing approach, which used bacterial transposase $\operatorname{Tn} 5$, to directly fragment and prime the RNA/DNA heteroduplexes generated by reverse transcription [90]. It offers a protocol for simple and accurate RNA characterisation and quantification. For full integration of large-scale genomics into the clinic, development of easy-to-operate sequencing protocol, which is fast, scalable, and cost-effective, will hold promise for use in high-quality and high-throughput RNA sequencing applications. The S protein of SARS-CoV-2 is recently found to be identical with the sequence of functional gene isolated from the virus of pangolin [91]. This suggests an evolutionary 
change happening in virus can be monitored through the genome sequencing. Hence, a new insight on evolutionary changes was demonstrated through genomic data analysis by Tang et al. [92]. They came up with their examination on S84L AA and their function in changing the ORF8 part thus presenting the effect of mutation on the pathogenesis of SARS-CoV-2. This kind of study can help researchers to identify and track the evolutionary changes in virus which in turn can aid to improve the detection methods [93].

\section{Loop-mediated isothermal amplification methods}

The loop-mediated isothermal amplification (LAMP) method works on the principle of nucleic acid amplification that uses the Watson-Crick base pairing. The amplified DNA and the RNA strands marked by the primers are analysed best through the gel electrophoresis. For example, the LAMP assay was applied for the SARS identification by first selecting the ORF1b region of SARS-CoV. Then, the ORF1b region was amplified to recognise them; then, it was marked by primer before being finally identified via gel electrophoresis [95]. The SARS early-stage diagnosis using real-time LAMP was reported by Thai et al. in 2004 [96]. Authors used the loopmediated amplification, where the loop F and loop B were prepared for amplification. Both the positive and the negative controls were applied. The result was monitored through Loop amp real-time turbidimeter and the threshold value within 0.1 with the turbidity within $60 \mathrm{~min}$ was considered to be positive with the sensitivity of 1 PFU detection limit. The real-time LAMP was also used during the MERS outbreak that detected the RNA of MERS-CoV with the sensitivity of 0.02 to 0.2 PFU [97].

An advanced method of LAMP is the sequence-specific criteria, which is a robust technique that can oversee the isothermal amplification and the LAMP simultaneously. The specificity is due to the fact that the technique is able to distinguish and filter the signal from noise which is the drawback in most methods. In this technique, most of the reports use a dye for fluorescent quenching to realise easy readout. But some of the research brilliantly used a one-step strand displacement in place of the standard dye and studied the sequence-specific amplification. Surprisingly, the crossreactive disturbance was sorted and at the same time it took only maximum $50 \mathrm{~min}[98,99]$. The real-time LAMP assay is considered to be advantageous since it does not require expert operation as well as it is simple and rapid in terms of reaction and also aids in easy detection for example in identification agarose gel electrophoresis. Compared to the real-time PCR, the real-time LAMP amplification takes only less than an hour; audit is also performed by simply mixing the components such as the primer, reverse transcriptase, DNA polymerase, and a supporting buffer in a tube and incubation followed by amplification. In terms of specificity, the real-time LAMP is dominant over the RT-PCR because the former uses six primers to detect eight DNA regions.

Now for the COVID-19, isothermal LAMP assay developed for calorimetric observation is being studied because of two reasons. First, the isothermal LAMP does simultaneous reverse transcription and amplification when the $\mathrm{pH}$ of reaction changes to detect the RNA directly. Second, during this change, using a $\mathrm{pH}$ indicator, the visual readout can be possible [90]. The detection limit was also comparable with the real-time PCR for the clinical sample and it was found that the reaction time was almost the same in both methods. However, the known reaction time for the real-time RT-PCR is $2 \mathrm{~h}$ while the LAMP-based emerging assays can be accomplished only within 20 to $30 \mathrm{~min}$. Very similar to this report, Mohammed et al. used the leucocrystal violet dye for the detection of Claustral $\mathrm{X}$ amplified with LAMP primers, the sequence of COVID-19 virus (Fig. 1(c)) [59, 71]. Previously, the flow visualisation strip was designed in capturing nucleic acids of the MERS-CoV through the LAMP assays [100], in which researchers created the cross primers to target the $\mathrm{N}$ gene. The two loops contained the biotin and the fluorescein isothiocyanate as a marker, and after binding with the streptavidin through the gold nanoparticle to form the complex, two loops captured the antibodies. ORF 1a, ORF1b, and the E gene of the MERS-CoV were firstly amplified using RTLAMP by Shirato et al. in 2014, which had a significant involvement of side reactions [101]. In converse, another research team developed a primer-based LAMP assay combined with the real-time proliferation that amplified the open reading frameworks of genes belonging to the MERS-CoV which successfully overcame the cross-reactivity while detecting the plaque-forming units up to 0.2 units [97]. Recently, Shirato et al. developed a specific fluorescent RT-LAMP using quenching probes for the detection of MERS-CoV, avoiding the influence of cross-reactions [102]. Now for the SARS-CoV-2, the RT-LAMP is performed in a single step within 40 min to target the $\mathrm{S}, \mathrm{E}$ and $\mathrm{N}$ gene at isothermal conditions processed at $63{ }^{\circ} \mathrm{C}[103]$. Moreover, the evaluation of the result is made more comprehensive using different technical asserts such as electrophoresis and real-time turbidimeter instead of relying only on fluorescence methods. As the fruit of current advancements in research, two-step amplification called the Penn-RAMP that combines the advantage from both amplification and LAMP is identified as an improved sensitive POC molecular-based method for detection [59, 104]. Therefore, LAMP can be a potential tool to be used as the POC method for diagnosis of human coronaviruses during the outbreaks.

\section{CRISPR/cas-based methods}

Beyond its remarkable genome editing ability [105], CRISPR/ Cas systems have demonstrated huge success in molecular 
diagnosis $[106,107]$. In addition to the capability to detect nucleic acids, CRISPR/Cas systems can be used for detection of non-nucleic acids. Recently Broughton et al. developed the lateral flow assay employing the Cas 12 as a reporting transmolecule to target the endonuclease [108]. The total process involves the combined effect of the amplification and the reverse transcription working together taking only $30 \mathrm{~min}$ to get the final visual signal. The predefined coronavirus sequences targeting the $\mathrm{E}$ protein and $\mathrm{N}$ protein coding genes of the virus, could trigger the Cas 12 followed by cleavage of a reporter molecule confirming detection of the virus. This CRISPR-based DETECTR assay also remained free of cross-reaction and provides a visual and faster alternative to the RT-PCR with completely assured negative results during the diagnosis.

Activated CRISPR-C2c2 that targets the RNA is referred to as Cas13a. This is engaged these days for the collateral cleavage and thereby recognising the target RNA which detects the SARS and MERS and was sensitive to mRNA knockdown [109]. After this, the Cas9 engineered in the eukaryotic cells were studied in detail for gene expressions to understand the infection pathway [110]. Then the recombinase polymerase (RPA) is applied for the amplification of the single molecule

\section{a}
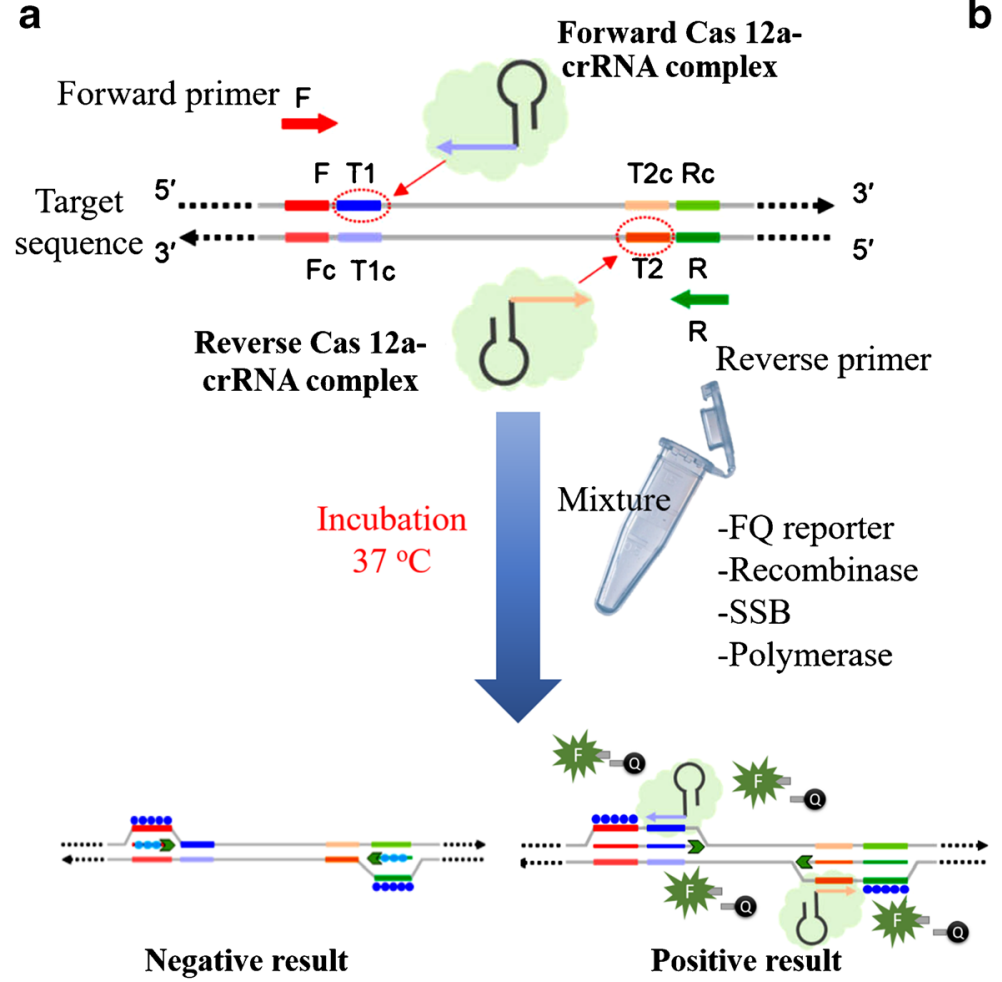

to the level of $10^{12}$, thereby eliminating the need to cleave the double stranded DNA. This technology was combined with the T7 RNA polymerase to detect the viral RNA at the level of $10^{-18}$. It is anticipated that this could be one of the real-time detection methods for the viral RNA assisted with the reported RNA [111]. Recently, an All-In-One Dual CRISPR-Cas12a (termed 'AIOD-CRISPR') assay was developed for simple, rapid, ultrasensitive, one-pot, and visual detection of coronavirus SARS-CoV-2 and HIV virus with a sensitivity of a few copies [94]. In this AIOD-CRISPR assay, a pair of crRNAs was introduced to initiate dual CRISPR-Cas12a detection and improve detection sensitivity. CRISPR/Cas systems have demonstrated great success in nucleic acid detection. The AIOD-CRISPR assay proposed by Ding et al. [94] targeted both the SARS-CoV-2 and the HIV-1 by involving pair of crDNA to the CRISPR system. This assay was efficient by replacing the common pre-amplification methods and post transferring steps. Typically, in this assay, the authors used the ssDNA with fluorescent FQ reporter and quencher to produce the visual colour change when the nucleic acid was detected (Fig. 2). Lucia et al. [112] provided a proof of concept on fast, sensitive, and handy POC testing based on principle of CRISPR-Cas 12 for the detection of the RNA of SARS-CoV-

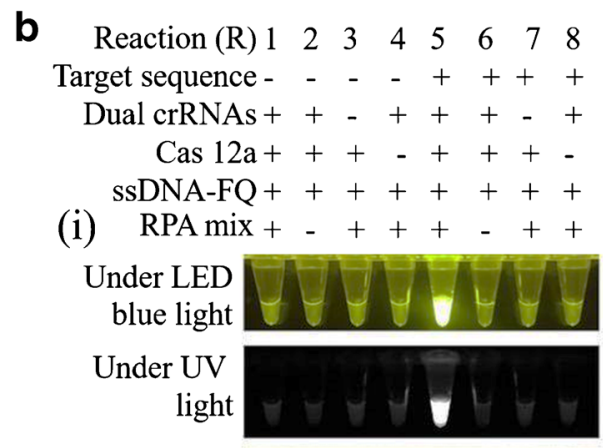

No excitation
(ii) light

(iii)



Fig. 2 (a) Schematic illustration for the working principle of All-In-One Dual CRISPR-Cas12a (AIOD-CRISPR) assay: demonstrating the stimulation of RPA amplification to reveal the binding sites of Cas 12acrRNA which turns on the fluorescence on activation of the endonuclease enzyme. (b) Designing and analysing of AIOD-CRISPR assay: The ssDNA-FQ reporter molecule was first marked with the fluorophore-5' 6-FAM and a quencher, which was subsequently put through RPA reactive treatments: (i) the reaction system showing direct visualisation of bright fluorescence under LED, blue light, and UV light; (ii) the reactive system number 5 produces highest bright signal due to the presence of smaller DNA sizes cleaved from the reporter molecule; (iii) graph indicating the saturation of highest produced fluorescent signal in 13 min [94]. Reproduced with permission 
2. In this method, the RdRp, ORF1b, and ORF1 ab were used as reference genes and the amplification of the target was carried out by typically using the RPA. Finally, the CRISPR-complex was prepared by adding sgRNA and LbCas 12a endonuclease which was made for the plate reader. For the assay based on the plate reader, the ssDNA labelled with FAM was used and for the portable configuration, the biotin labelled ssDNA was used on the paper strips. Here, the fluorescent measurements were applied to study the plate reading assay and lateral flow system was applied for paper strips. Although the developed CRISPR-Cas 12 presents lower detection limit, its application in clinic will be discouraged due to tedious sample preparation steps. So far, to the best of our knowledge, the CRISPR methods are only associated with lab procedures yet not demonstrated in practical applications, which might be due to the high cost, and the complicated operational process $[105,111,113]$.

\section{Antibody-based serology detection}

Antibodies can be described as the body's specific proteins that are produced by the white blood cells to line against the foreign particles or infections. Antibodies are the protuberant for the immunotherapy and it differs from PCR methods by prevailing the immunity or they remain in the blood even after the infectious are removed. Thus, antibodies leave the trace of its mechanism in the body after its action and make it possible to identify those become immune after COVID-19 infection. Therefore, being specific to COVID-19, a very precious activity of these antibodies is that they protect the COVID recovered patient from re-infection, while the PCR methods are not able to do this. Additionally, antibody-based detections are more beneficial in terms of finding the number of infected and recovered patients especially for a large number of samples. Currently, two strategies are used for detection of antibodies for diagnosis of COVID-19 infection. One is to design the antigen that mimic the antigen of virus to detect the human antibody and the second is to design the test antibody that trap the viral antigen.

Based on the recent studies, an overall timeframe for the generation of antibodies (IgM, IgG) and antigen were shown in the Fig. 3 for SARS-CoV-2 infected patients. The IgM antibodies are expressed only after 3 to 7 days of infection and robust responses can be obtained in second week of infection, while the $\operatorname{IgG}$ antibodies take 8 days to reach the detectable level. The antibodies are present in the blood and only detectable from the blood samples, while the RT-PCR requires only the respiratory tract fluids as samples for the diagnosis. The antibody-based methods are not useful in the early diagnosis as it can be adopted only after infection and makes the situation difficult by not being able to find if the patient is already recovered or newly infected. This in turn makes it difficult for the experts and the government to find the accurate number of prevailing infections. Based on guidance from the World Health Organization and other related agencies, antibody-based serological testing is not well-suited for diagnosis of acute SARS-CoV-2 infections and should be restricted to epidemiological studies.

During the SARS-CoV-1 and the MERS-CoV's period, several immunoassays were developed for detection of antibodies but all of those are reported to have the cross-reactivity [115-117]. It was found that the non-structural proteins called as NSP were present in different species of the coronaviruses and based on this the serological detections in patients were conducted during 2004 [118]. But the biggest drawback is that the antibodies developed against the virus reacted with the cross-reactive antibodies of the immunogenic leading towards false-positive results in those without COVID-19. Particularly, in the case of MERS-CoV detection, the common target of the
Fig. 3 Comparative relation theoretically between different levels of SARS-CoV-2 RNA and antigen, IgM and $\mathrm{IgG}$ during the different infection days showing three main phases such as window period, decline phase, and convalescence phase. In the window period, the onset of symptoms takes place within a week of contact with viral source. Secondly, the IgM shows up and the production of $\operatorname{IgG}$ takes place until it disappears in 21 days of infection. Thirdly, in the recovery, the IgG remains in the blood. This suggests that the serological examination could be done 3 days after the symptoms or a week after the infection [114]. Reproduced with permission

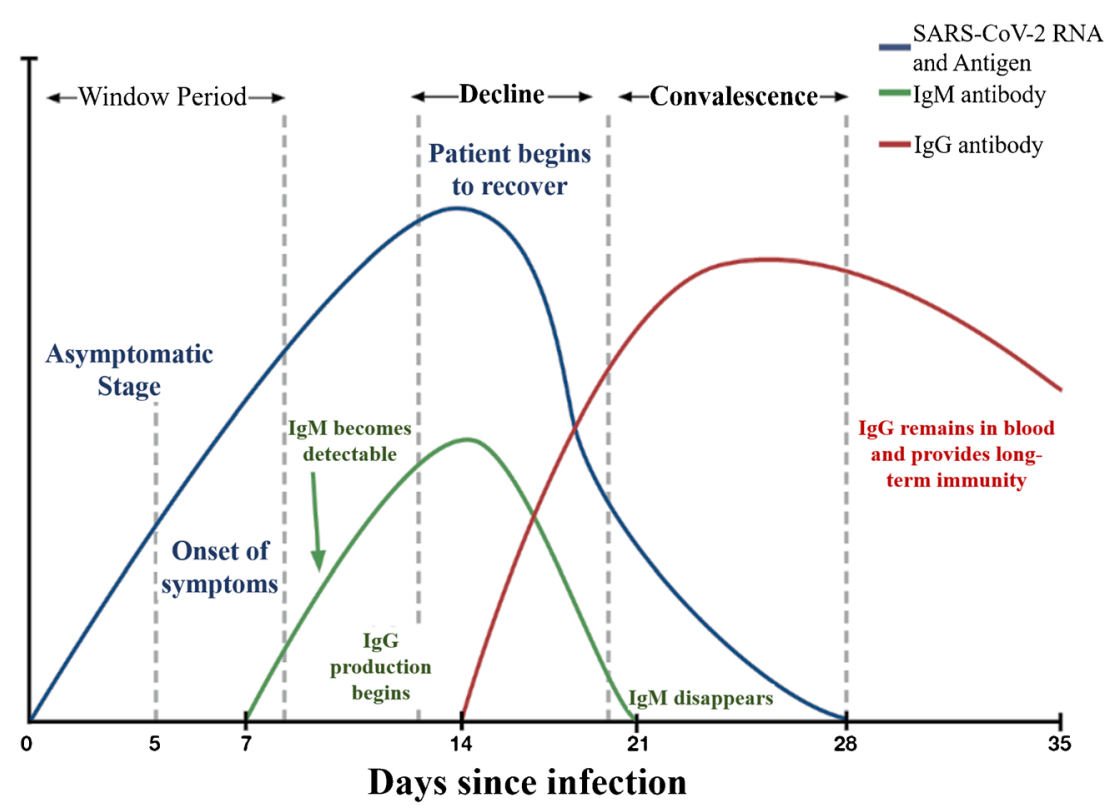


viral part was the $\mathrm{N}$ and $\mathrm{S}$ proteins which are considered to be immunogenic and these are currently used to produce the recombinant antigens [119]. And, laboratories applied several neutralisation assays such as microneutralisation and pseudo particle neutralisation while handling the live MERS-CoV [120-122]. Even though the immunosensors for the determination of SARS-CoV-2 were still not developed, some immunosensors working on the principle of photoluminescence, immobilisation, capacitive resonators, and electrochemical methods were studied. For example, the gp51 proteins of bovine leukaemia virus and their antibody-antigen detection were investigated through surface plasmon resonance. But the detection limit was $0.0028 \mathrm{mg} / \mathrm{mL}$ [123]. Following this, few fragments of the antibodies in response to this viral antigen gp51 were applied as the recognition sites and analysed using quartz crystal microbalance after being immobilised with gold nanoparticles. As a function of varying mass densities on the surfaces, this system helped in displaying the ratio of responses [124]. Likewise, the gp1 protein was also functionalised on coated gold surface and silicon nitride surface to study their interactions based on the change in frequencies [125]. Apparently, the electrochemical method developed by conjugating the polymer with this viral protein resulted in potential changes where at $950 \mathrm{mV}$ the conjugation was detected [126]. Then recently in 2019, the same viral protein was immobilised on the $\mathrm{ZnO}$ nanorods and the nanorods were examined for the reactive antibodies on the nano surfaces under photoluminescence [127]. The photoluminescence shift from 499 to $516 \mathrm{~nm}$ confirmed the electrostatic interaction, between the nanorod and the viral protein that produced a variation in the electric field that worked through the biosensor performance [128].

\section{Enzyme-linked immunosorbent assay}

Enzyme-linked immunosorbent assay (ELISA) cannot be used in a practical way like the RT-PCR since they are bound to work well only in the lab environment. For the COVID-19, the IgM and the IgG of the patients are mainly tested because IgG is the immunoglobulin that is highest produced when the viral antigen is exposed and the IgM gives the first response which can be used for the detection at the early stage of infection. The detection of IgA antibodies in animal mucosal surface (pig) is prevalent while it is not the same in human [129, 130]. Trivedi et al. [131], in 2019, developed the immunoassay to detect the human IgG antibodies against the six types of coronaviruses. The typical assay comprised the multiplexed magnetic microsphere immunoassay in serum sample by which the authors detected the IgG responses against the nucleocapsid protein of the viruses such as human coronaviruses 229E, NL63, OC43, HKU1, SARS-CoV, and MERS-CoV. In this study, paired human sera were used for IgG screening against six human coronaviruses. Based on their results, no interference between monoplex and multiplex modes was observed and $86 \%$ sensitivity as well as $84 \%$ specificity was obtained.

The diagnostic amount of IgG was also examined by Guo et al. [54], along with other immunoglobulins IgA and IgM by coupling the ELISA with the PCR. To this end, the nucleocapsid genome of SARS-CoV-2 collected from the infected patient was expressed by amplification methods in the positive strain of pET30a, followed by plasmid expressed in E. coli. The final recombinant $\mathrm{N}$ protein ( $\mathrm{rNP}$ ) was purified and confirmed via western blot assay using the human monoclonal antibodies. This rNP was employed as coating antigens in ELISA plates and demonstrated the antibody-based sub clinical analysis indicating that it is useful when the qPCR test falls negative. The kinetics on time and potential of different antibodies against the SARS-CoV-2 tested by them paves a new way to understand the diagnostic value of antibodies. The median duration of 5 days (for IgM and $\operatorname{IgA}$ ) and 14 days (for $\mathrm{IgG}$ ) after symptoms onset was observed for antibodies detection. More importantly, it was shown that the detection efficiency by IgM ELISA is higher than RT-PCR after 5.5 days of symptoms. Moreover, combination of ELISA with RT-PCR gave a significant raise to positive detection rate $(98.6 \%)$ while the results are compared with single qPCR (51.9\%).

The antibody tests combined with PCR are said to be an efficient method of choice, yet not proved as an efficient practical tool at the same time. Likewise, the virus counteracting antibodies, and the antibodies against the nucleocapsid protein as well as the receptor binding domain was described through ELISA. For this, the sera from the COVID-19 patients were used as samples and the coated 96-plate ELISA with the spiked antigens of SARS-CoV-2 was exploited and found through PRNT assay the sera neutralised the virus. However, in this test, the IgA-based ELISA showed higher sensitivity compared to the IgG ELISA. But the low specificity and cross-reactivity were still a problem indicating that the assay has response towards some other protein apart from the coated specific antigen [132]. Apart from this, Khan et al. [133] developed the lyophilised viral antigen microarray probed with the human serum that was labelled with the secondary antibodies. Under the saline control, the unbound antibodies were eliminated, and statistical analysis was performed. This methodology was used to study IgG reactivity against antigens associated with epidemic and common human coronaviruses. It was shown that antibodies to $\mathrm{S} 1$ domain and receptor-binding domain (RBD) of spike protein are highly sub-type specific, while S2 domain of spike protein and nucleocapsid protein is more cross-reactive.

Currently, Berlin-based Pharmact developed the 12-min immunoassay which contains N, S1 and S2 glycoprotein of the virus and can recognise the antibody of a patient that responds for these proteins. It is also said to detect both the early and later stages of infection by the IgM and IgG antibody responses. Very recently, assay based on ELISA was 
performed where the $\mathrm{S} 1$ protein of the corona virus was applied as an antigen in the kit [134]. This is said to be useful for the medical practitioners and staffs as it could detect the infection early when working in a COVID environment in hospitals and laboratories. Such a technique was also examined against 412 samples of human origin and was found to provide $97.5 \%$ accuracy. It is worth to note that, even though the neutralisation method is quite acceptable in research sectors, the main difficulty associated with this is, it requires the viral culturing which requires a high level of safety standard, very qualified operators and high-quality biosafety facilities to run this. On the other hand, the ELISA is only based on the principle of binding, which means it is a form of readily available, designable and ease of handling which is more suitable for POC types. The diagnostic value was also found from developing a new ELISA assay proposed by Liu et al. [135], who demonstrated the assay against the viral $\mathrm{N}$ protein. The mouse anti-human monoclonal antibody IgM-coated ELISA plate was prepared, where the specimen typically the serum was added. Following subsequent incubation, the viral recombinant protein was added to the wells. Likewise, for the detection of IgG, the plates were coated with viral recombinant protein where the sample was loaded passing through incubation. This was then added with the conjugated mouse antihuman IgG antibody. This resulted in $50 \%$ of positive cases through IgM/IgG ELISA-based detection method. A very recent study based on both serological and nucleic acid technique on the serum and sputum samples by $\mathrm{He}$ et al. [136] conveys that the serological techniques can be used as a complementary method for the detection of COVID-19 infection after being confirmed with the nucleic acid-based test.

\section{Lateral flow immunochromatographic assays}

The lateral flow immunochromatographic assays are predominant in the point of care (POC) devices as cost-effective, rapid, and easy-to-handle test strips inside labs or in situ personal healthcare monitoring. These devices are also wellsuited for commercialisation and mass production. In general, the lateral flow assays express red or pink line on strip only if the human antibody, the viral antigen, and the gold nanoparticles complexes get together at $\mathrm{M}$ or $\mathrm{G}$ line. While the presence of other antibodies produces no visual colours. Li et al. [137] developed a lateral flow assay test strip for specific detection of COVID-19. They used the anti-human antibodies of $\operatorname{IgG}$ and $\operatorname{IgM}$ and utilised the recombinant antigen (MK201027 from the spike protein). This recombinant antigen was the receptor of SARS-CoV-2. They mixed the gold nanoparticles with the recombinant antigen followed by incubation, centrifugation, and re-suspensions to form the AuNPCOVID-19 antigen conjugates. The anti-rabbit IgG antibody was set as the control line and the conjugate pad was sprayed with AuNP-COVID-19 antigen conjugate and AuNP-rabbit
Ig $G$ conjugate. The anti-human $\operatorname{IgG}$ and $\operatorname{Ig} M$ were immobilised in $\mathrm{G}$ and $\mathrm{M}$ test lines, respectively. Finally, the assay was performed by using the 1 to 2 drops of blood sample on the pads (Fig. 4(c)) [114]. This lateral flow assay test strip could simultaneously detect IgM and IgG within 15 min. Clinical studies were carried out by blood sample analysis of PCR-confirmed infected cases and negative patients. According to the obtained results, $88.66 \%$ testing sensitivity and $90.63 \%$ testing specificity was achieved. Another lateral flow assay capable of providing antibody signals in just 10 min with 95\% accuracy was introduced for SARS-CoV-2 using the kit currently named ERA-BIO [139].

\section{Antigen detection-based methods}

RT-PCR is used to detect the viral genetic material, and antibody testing detects human antibodies against the virus. As discussed in the above section, four popular proteins are associated with the surface spikes of coronaviruses. Antigen tests is to identify fragments of viral surface proteins as a marker providing a direct and rapid mean for early diagnosis of infection, without the requirement to use expensive equipment like PCR for signal amplification. In theory, a reliable antigen test is easy to be developed as soon as the antibodies are available. The recombinant antigens are now available in formulations such as recombinant nucleocapsid (N protein), spike protein (S protein, $\mathrm{S} 1+\mathrm{S} 2 \mathrm{ECD}$ ), spike protein (S1 protein), spike RBD protein, envelope (E protein), 3C-like proteinase. These information and specific antigen suitable for the specific antibodies are provided in the source link [145].

Recently, Diao et al. have successfully developed a fluorescence immunochromatographic to detect the $\mathrm{N}$ protein of SARS-CoV-2 in urine and nasopharyngeal swab samples (Fig. 4 (d)) [146]. The goat anti-rabbit IgG antibodies and the monoclonal mouse anti-nucleocapsid protein of SARSCov-2 were dotted on nitrocellulose membranes as control lines and test lines, respectively. While the conjugate pad was spotted with carboxylated polystyrene Europium (III) chelate microparticles conjugated with NP protein of SARSCov-2 monoclonal antibody or rabbit IgG. Using their method, the whole assay could be carried out in $10 \mathrm{~min}$ and NP protein could successfully be detected in urine samples of $73.6 \%$ of confirmed cases. It shows $100 \%$ of nucleocapsid protein positive and negative participants accord with nucleic acid test for same samples. A similar method called rapid antigen detection test (RDT) was also reported by Lorena et al. [147]. This new fluorescence immunochromatographic SARS-CoV-2 antigen detection test (Bioeasy Biotechnology Co., Shenzhen, China) was evaluated in nasophayngeal (NP) and oropharyngeal (OP) swabs from patients with suspected COVID-19 in Santiago, Chile. Diagnostic accuracy was determined in comparison to SARS-CoV-2 RT-PCR, using the same material (universal transport medium with NP and OP 


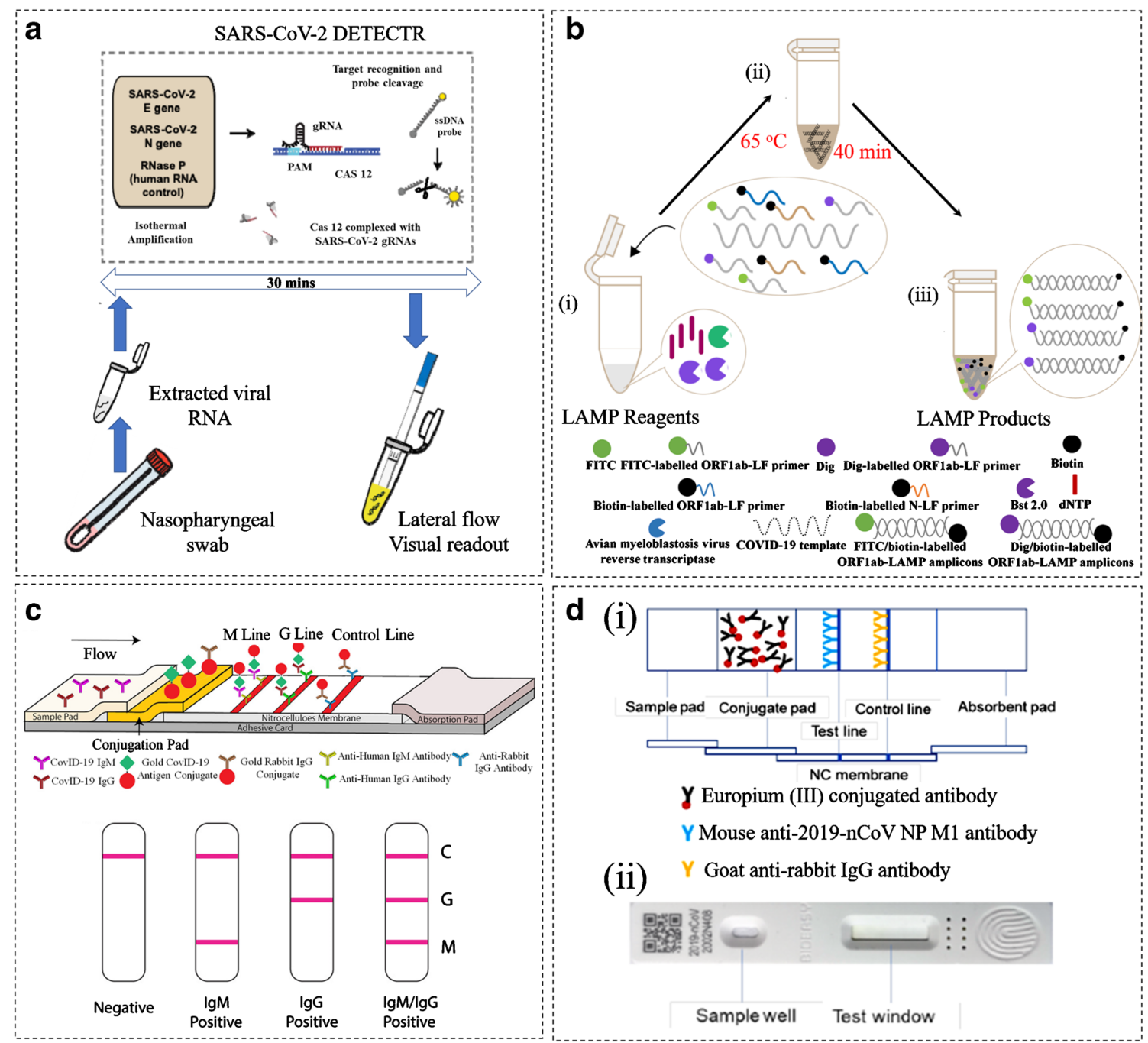

Fig. 4 Demonstration of lateral flow immunochromatographic assays for the diagnosis of COVID-19: (a) A CRISPR-CAS12-based assay for detection of viral nucelic acid where the viral RNA was extracted from the swab sample and amplified. Then, as a control, the DETECTR assay was carried out on E, N, and human RNase P gene for $30 \mathrm{~min}$. This was applied for RT-LAMP and Cas 12 detection at $62{ }^{\circ} \mathrm{C}$ and $37^{\circ} \mathrm{C}$ [138] (reproduced, permission has taken under the CC-BY-NC-ND 4.0 International license). (B) RT-LAMP-NBS assay for COVID-19 detection: (i) The amplification mixtures were prepared as LAMP reagents shown in legends, (ii) The RT-Lamp reaction was conducted at $63{ }^{\circ} \mathrm{C}$ for $40 \mathrm{~min}$, (iii) The products FIT/biotin-labelled F1ab-LAMP amplicons and np-LAMP amplicons formed [71]. Re-produced, permission has taken under the CC-BY-NC-ND 4.0 International license. (c) Diagrammatic representation of $\operatorname{IgM}-\operatorname{IgG}$ antibody test strip: The mouse anti-human monoclonal antibodies IgM and IgG were set as the test lines ' $\mathrm{G}$ and $\mathrm{M}$ ' on the strip, and the anti-rabbit IgG antibody was used as the control. Then the SARS-CoV-2 antigen was added to the gold colloid to form a conjugate nanoparticle. This was introduced on the pad

through spraying on the surface that contains the specific SARS-CoV-2 antibody test lines. Likewise, the gold nanoparticle conjugate of rabbit IgG was also sprayed along to fix with the control line 'c' constructing a lateral flow device. The test was performed by running up to $15 \mu \mathrm{L}$ of specimen and the analysis were determined from the ' $c$ ' zone by visualisation of redpurple line for the SARS-CoV infection [137]. Re-produced, permission has taken under the CC-BY-NC-ND 4.0 International license. (d) Graphic representation of immunochromatographic strips working under fluroscence: (i) The control line was coated with goat anti-rabbit IgG antibody, the test line was coated with the mouse anti-2019-nCoV NP M1 antibody as shown in the legends. Here the conjugae was the Euphorbium (III) treated with carboxylate that was conjugated to the antibody. (ii) The assembled strip within the plastic cassette containing a well for the sample loading and a testing window. The results through this immunochromatographic technique can be determined when the fluorecent signals are captured through immunofluorecence analyser [4]. Re-produced, permission has taken under the CC-BY-NC-ND 4.0 International license

swab). The assay was easy to use and provided results in a timely manner. However, the sensitivity and specificity of RDT depends on time of infection, concentration of infected samples and specimen quality. This is similar to previous observation on the antigen test for respiratory viruses, such as influenza, which has a decent sensitivity of about 70 to $80 \%$

when run properly on a good nasal swab - but only for children (the quantity of the virus in children is typically much higher than in adults) [148, 149]. Although antigen tests are simple and direct, the specificity and sensitivity are limited by several factors including the quality of antibodies and the patients. Thus, combination of antigen tests with nucleic acid 
and antibody detection is to maximise its ability for accurate human coronavirus diagnosis. Recently, the lateral flow assays and isothermal amplification method is identified as the emerging diagnostic methods for SARS-CoV-2 [150, 151]. The lateral flow assay is discussed in the 'Lateral flow immunochromatographic assays' section, while the isothermal amplification is a simplified version for RT-PCR which comprises the RT-LAMP method described in 'Loop-mediated isothermal amplification methods' section.

\section{Currently emerging clinical diagnosis}

In addition to the above chemical diagnosis methods, $\mathrm{CT}$ is considered first-line imaging in suspected cases to screen the respiratory pneumonia caused by coronavirus. CT is also used as clinical characteristics of the recovered COVID-19 patients with re-detectable positive RNA test [153]. There are four different scanners in CT Anatom 16 HD, 64-MDCT lightspeed, Hispeed duel, and Somatom emotion. The obtained radiological images of pneumonia caused by COVID-19 showed a clear destruction of the pulmonary parenchyma such as interstitial inflammation and extensive consolidation [154]. Exploring the $\mathrm{CT}$ and understanding of interpretation can be found from the report of Pan et al. [154]. In this study, they investigated pulmonary $\mathrm{CT}$ evaluations for infected cases in a timeframe of 0-26 days. Based on their investigation, the most frequent $\mathrm{CT}$ observations in mild COVID-19 pneumonia were ground glass opacities, crazy-paving pattern, and consolidation. More interestingly, they identified four stages from the onset of symptoms. These stages include stage 1 ( $0-4$ days), stage 2 ( $5-8$ days), stage 3 (9-13 days), and stage 4 (14 days and more). In each stage, the lower lobes were more inclined giving raise to $\mathrm{CT}$ scores and the highest $\mathrm{CT}$ score was obtained in 10 days after the onset of initial symptoms [155]. Song et al. [156] developed an automatic differentiation method for the real-time identification of COVIDS-19 infection based on the CT scan. The sensitivity and specificity obtained through this analysis from CT image were $92 \%$ and $91 \%$, respectively. Clinical diagnosis is facing far big challenges and difficulties because it is not developed as much as laboratory detection methods such as the serological and molecular diagnosis methods. Currently, the RT reverse transcription method of PCR is identified for clinical detection called as the swab test. Wang et al. [157] got the ethical permissions for the clinical detection trials and the suspected were let for the diagnosis. In their trials the blood, sputum, human wastes, and samples from the respiratory tracts were analysed from RNA derived through RT-reverse transcription PCR method. As a supporting investigation the authors also studied the live cells cultured visualised via electron microscopy. In the end, they found nearly 40 positive cases from the clinical samples analysed. The swab test and reliability through transistor biosensors are very recently investigated. As such the FET devise for sensing was proposed by Seo et al., who detected the $\mathrm{S}$ protein of SARS-CoV-2 in $1 \mathrm{fg} / \mathrm{mL}$ concentration (Fig. 5) [152]. Likewise the photothermal sensing methods are becoming competent to the PCR methods to minimise the falsenegative and false-positive results [158]. While the impact of thermal activation has been analysed in nucleic acid test to reduce the false-negative results [159]. Although PCR is identified to be beneficial in swab test yet, the only recognised and reliable clinical diagnostic method is the radiology and the CT. But the radiology results do not show specific patterns

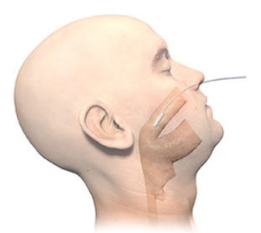

COVID-19 patient
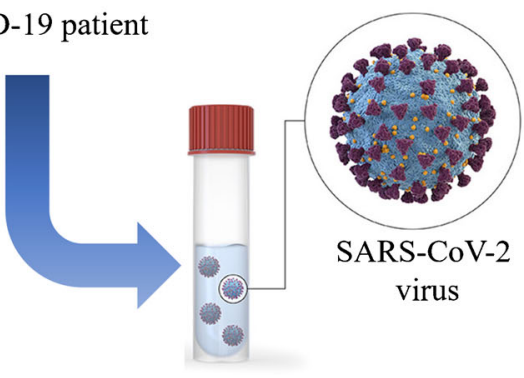

virus

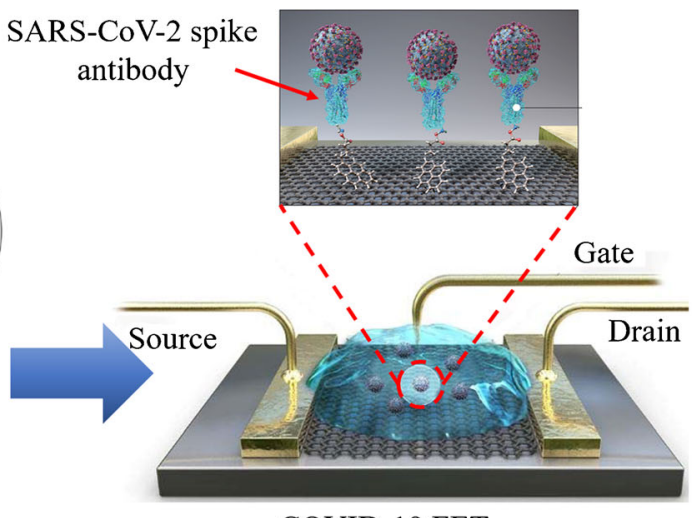

COVID-19 FET sensor

N-hydroxysuccinimide ester $(\mathrm{P}$ This forms the conjugated graphene sheet capable of detecting $1 \mathrm{fg} / \mathrm{mL}$ of viral antigen [152]. Reproduced with permission
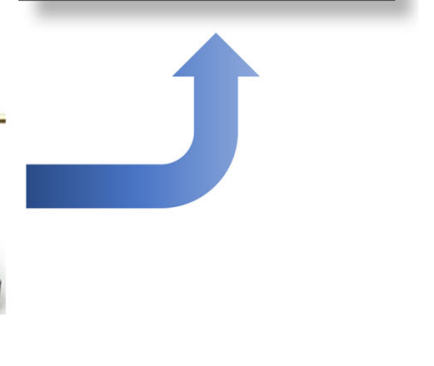

Fig. 5 Graphically representation of FET sensor for COVID-19: Firstly, a carbon-based biosensing platform was constructed by functionalising the graphene with viral spike antibody. The functionalisation was done via immobilisation technique, where a coupling agent 1-pyrenebutyric acid

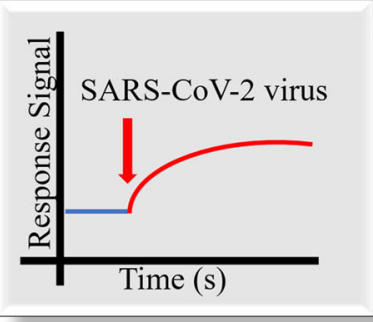


for COVID-19 and the obtained radiological images provide similar information for all coronavirus infections [160].Therefore, the molecular methods are now used in diagnosis of COVID-19 due to emergency, the lack of costeffective clinical diagnosis methods, and dire necessity to new diagnostic tools [161]. But recently, 98\% clarity via radiology with $97 \%$ accuracy in ResNet50 model has been found which is the gift of scientific development in current days [162].

\section{Pros and cons of different methods for human coronavirus diagnosis}

Diagnosing viral infections currently relies on three major methodologies: real-time RT-PCR, immunoassays based on antibodies to detect viral antigen so called serological method and CT scanning. Molecular, serology and emerging methods discussed in this review have their own advantages and inherent disadvantages as well. Table 2 compares the advantages and disadvantages of these methods. The genomic sequencing method was first used to diagnose the virus causing the disease during the early stages of the COVID-2019 outbreak. Typically, the partial or the complete genome of the SARS$\mathrm{CoV}-2$ genome from the patients were collected. These were sequenced at the terminal regions and the cDNA were amplified using Sanger sequencing. The phylogenetic analysis of genomes was used to differentiate the SARS-CoV-2 from other viruses [21]. But the method was too expensive and complicated at the same time, and specially, it was not helpful for large number of samples. Then, the RT-PCR methods working fundamentally on the viral proteins were widely used to detect the viral RNA. Although RT-PCR is the gold standard for the nucleic acid detection, their operation needs enough concentration of viral RNA in patient sample for specimen analysis. This can be a major drawback since the consistency in concentration of the viral RNA is not constant and their amount cannot be controlled to satisfy the specimen analysis. This method is so sensitive that sometimes it can result in false-positive results. In addition, the same patients can exhibit varied concentrations of viral RNA from time to time and also the concentration is not similar among different group of patients. Thus, this immediate need cannot be compromised for the reliable diagnostic method. Coming to their technical issue, there is no constant sampling method, and the level of efficiency depends on the proficiency of the individual operator added on with the difficulties in swab collections. The inaccurate sampling in turn leads towards false-positive and false-negative results [148]. After sampling, another main problem associated with RT-PCR is the complexity in operations since these detections require highly qualified technicians to perform complex RNA extraction steps and PCR. Moreover, the specimen collection and processing are found to infect the technicians and the doctors widely spreading the disease and creating a contaminated environment to the community. The cross-contamination or the crossreaction was another major drawback associated with RTPCR, which can result in a number of false-negative and false-positive test results [163].

Serological assays since 2001 are becoming a compliment against the molecular methods mainly due to the effectivity in finding the source of infection. The antibody-based serological detections are less expensive with quick resulting time

Table 2 Comparison of performance of different methods for coronavirus diagnosis

\begin{tabular}{|c|c|c|c|c|c|c|}
\hline $\begin{array}{l}\text { Detection } \\
\text { methods }\end{array}$ & $\begin{array}{l}\text { Assay } \\
\text { time }\end{array}$ & Specificity & Accuracy & Advantages & Disadvantages & References \\
\hline $\begin{array}{c}\text { Nucleic acid } \\
\text { detection }\end{array}$ & 4 to $6 \mathrm{~h}$ & $95 \%$ & $\begin{array}{l}\text { Poor accuracy, the exact } \\
\text { percentage is not } \\
\text { revealed }\end{array}$ & $\begin{array}{l}\text { High sensitivity, possibility } \\
\text { of large-scale operation }\end{array}$ & $\begin{array}{l}\text { Professional technicians needed, } \\
\text { difficult data analysis, expensive, } \\
\text { less accuracy, false-negative or } \\
\text { false-positive results }\end{array}$ & {$[140,141]$} \\
\hline $\begin{array}{l}\text { Gene } \\
\text { sequencing }\end{array}$ & Unknown & Poor sensitivity & Poor accuracy & $\begin{array}{l}\text { Finding the evaluation of } \\
\text { virus, identification of } \\
\text { mutation, }\end{array}$ & $\begin{array}{l}\text { Experts and trained personnel } \\
\text { needed, time consuming, costly, } \\
\text { and complex data analysis. } \\
\text { Laboratory and clinical } \\
\text { differences }\end{array}$ & [142] \\
\hline $\begin{array}{l}\text { Antibody } \\
\text { detection }\end{array}$ & $15 \mathrm{~min}$ & $90.63 \%$ & $88.66 \%$ & $\begin{array}{l}\text { Easy handling, no } \\
\text { requirement of expert }\end{array}$ & $\begin{array}{l}\text { Long window period, difficulty in } \\
\text { early diagnosis, detection only } \\
\text { after } \\
\text { post infection from } 3 \text { to } 6 \text { days } \\
\text { for IgM and } 8 \text { days for IgG }\end{array}$ & [143] \\
\hline $\begin{array}{l}\text { Antigen } \\
\text { detection }\end{array}$ & $\begin{array}{l}15 \text { to } \\
30 \mathrm{~min}\end{array}$ & Poor sensitivity & Poor accuracy & Easy handling & Not reliable & [15] \\
\hline $\begin{array}{l}\text { Clinical } \\
\text { diagnosis }\end{array}$ & 2 days & Not specified & Not applicable & $\begin{array}{l}\text { Finding the disease } \\
\text { through imaging }\end{array}$ & $\begin{array}{l}\text { Requirement of experts and trained } \\
\text { personnel, difficulties in early } \\
\text { detection }\end{array}$ & [144] \\
\hline
\end{tabular}


compared to the RT-PCR. Currently the ELISA methods are successfully prepared to detect the major IgM and IgG antibodies against the viral nucleocapsids and proteins [72]. Yet the demerit sustains by producing false positive since the nucleocapsid protein is conservative in human coronavirus genome. On the other hand, as described above in antibodybased detections, targeting the $\mathrm{S}$ protein is seeing an improvement currently. However, the main disadvantage prevailing is the serology-based detections are ineffective in early diagnosis of coronavirus impossible. Paper lateral flow assay-based methods have been used for detection of nucleic acids [71, 138], antibodies [137], and antigen [146] associated with coronaviruses. Although they have demonstrated advantages of being used in both in-lab and in-field, they are not approved widely by regulatory administrations because currently the reliability of such devices is poor for COVID-19. Clinical emerging method such as chest CT, which does the early screening of lung infections as well as finding the severity and stage of disease, has widely been accepted as an efficient clinical diagnostic method [164]. However, in patients at high risk for 2019-nCoV infection, chest CT evidence of viral pneumonia may precede positive negative RT-PCR test results [165]. Thus, combining the different strategies for testing the infectious samples and intensive correlation with CT scanning and analysis could possibly assist in the clarifications regarding the false screening in RT-PCR-based diagnostic.

\section{Conclusions and prospective}

Three novel human coronaviruses (SARS-CoV-1, MERS$\mathrm{CoV}$, SARS-CoV-2) are highly contagious and so it requires a stable detection tool to screen the threat like COVID-19 pandemic for further tackling. Currently, laboratory diagnosis of COVID-19 mainly relies on real-time RT-PCR tests to detect viral genetic material, and serological tests to detect $\mathrm{IgM} / \mathrm{IgG}$ antibodies. Although several advanced methods (such as LAMP, CRISPR/Cas systems) have been developed for detection of virus nucleic acids with high sensitivity, the virus nucleic acid RT-PCR test has become the standard method for diagnosis of COVID-19 infection from nasopharyngeal swabs. The power and advantages of RT-PCR have been well described in several great reviews $[67,166]$. In addition, RTPCR is also associated with disadvantages because the viral RNA is contagious and an biohazard alarm to the experts working on those detections, causing big threatens to medical workers, such as exposure risks to healthcare workers during the multiple steps of sample preparation and handling, and global shortages of swabs and personal protective equipment. RT-PCR has also been proved to have false negatives for current SARS-CoV-2 detection [167].

Serological antibody tests are not effective in early diagnosis, but simultaneous detection of both $\operatorname{IgM}$ and $\operatorname{IgG}$ could provide information on virus infection at different stages and help government to figure out who might be immune to the virus. Identifying people with immunity to the SARS-CoV-2 will give us the ability to know who do not need to be quarantined, and thus help to control the outbreak in the community and in hospitals. Serological tests are mostly around detecting the $\operatorname{IgG}$ and the $\operatorname{IgM}$ antibodies and provide few merits over the RT-PCR such as they can detect human antibodies while the molecular technique detects only the viral RNA. This offers the advantage of stability in the serological test since the IgM/IgG samples are stable that ease the collection of the specimen followed by transportation as well as in storing the specimen for examinations which is not facilitated for RT-PCR specimens. Second, the antibodies are prevalent in the blood and distributed evenly while the molecular specimens such as the RNA distributed in the respiratory tract is not consistent. Finally, the serological tests saves the history of infection by tracing the antibodies in the blood from several weeks to month while it is not the case in molecular method. At the same time, the antibodies follow sedate response scenario putting the serological tests under limitations in reaction towards the SARS-CoV-2. The current situation in sensitive and specific serology-based detections is that the active detection time falls latest on the third day of infection or 7 to 10 days after the infection. Although the serological tests based on the familiar interpretations on the IgM/IgG antibodies are not specific in differentiating the resistant and active infectious individuals, they can still be an effective diagnostic when coupled together with the RT-PCR technique. In addition, because of their scalability and easy integration with paper lateral flow assay, they help in aiding towards wide-scale POC diagnosis, while they also help in generating the document on the total of immune responses against the virus including the carriers as well. It is frequently people testing positive for SARS-CoV-2 are asymptomatic [168]. Thus, serological assays are especially critical to manage coronavirus infection and control the pandemic spread. As of today, researchers believe that the combination of both RT-PCR and IgM-IgG antibody tests can lead for accurate and more sensitive technique for the detection of SARS-CoV-2 virus [169]. Recently, CRISPRCas13a is getting more attention owing to their feasibility in eliminating the amplification steps while at the same time they shed lights in terms of POC diagnostics, and consequently eliminating possible background signal from amplification process [170]. The clinical methods like the $\mathrm{CT}$ and radiology are also only $85 \%$ successful on COVID-19 [55]. In future, developing the CT features for factors such as genome or genetics and multi-modelling disease diagnostics, clinical information would help the society. Other than this, the currently emerging laboratory techniques may be needed an intensive work which shall look for the clinical applications. Currently, all the methods available clinically or in lab are not accurate and super specific to challenge against the current COVID-19. 
But there is a scope to attack both the $\mathrm{N}$ protein and $\mathrm{S}$ protein in an assay, which will significantly improve the accuracy and specificity of the current serological methods.

To date, although considerable efforts on development of different assays are being done to detect this virus, the practical application with satisfactory results is still behind due to the viral structural complexity. A combination of different diagnostic methods could be a tactics. To achieve a costeffective and scalable POC device for fast, accurate, and non-invasive detection of human coronavirus in saliva is favourable to all parties $[23,39]$. The molecular, serological, and recently blooming CRISPR methods are also said to be promising scopes for the SARS-CoV-2 detection by Liu et al. [58]. Yet, tackling the mutating genes of virus, neutralising and in-depth findings on viral protein mechanism could help in designing new diagnosing methods or improve the existing ones. We are expecting to see more advanced diagnosis methods for human coronavirus as researchers disclose more biological properties of these novel human coronaviruses. We are confident that we will win the 'global war' against the current COVID-19 pandemic.

Author contributions Guozhen Liu: conceptualisation, revision, editing, administration, and funding. Mercy Rose Benzigar: drafting, editing, revision, and formatting. Ripon Bhattacharjee: revision and editing. Mahroo Baharfar: revision and editing.

Funding This work was supported by the ARC Future Fellowship (FT160100039), the UNSW-CAS Collaborative Research Seed Fund Program (172644KYSB20190059), the UNSW Digital Grid Futures Institute Seed Fund, and the UNSW Biomedical Engineering Seed Fund.

\section{Compliance with ethical standards}

Conflict of interest The authors declare that they have no conflict of interest.

\section{References}

1. Tyrrell DA, Bynoe ML. Cultivation of viruses from a high proportion of patients with colds. Lancet. 1966;1(7428):76-7.

2. Callow KA, Parry HF, Sergeant M, Tyrrell DA. The time course of the immune response to experimental coronavirus infection of man. Epidemiol Infect. 1990;105(2):435-46.

3. Valitutto MT, Aung O, Tun KYN, Vodzak ME, Zimmerman D, $\mathrm{Yu}$ JH, et al. Detection of novel coronaviruses in bats in Myanmar. PLoS One. 2020;15(4):e0230802.

4. Chamings A, Nelson TM, Vibin J, Wille M, Klaassen M, Alexandersen S. Detection and characterisation of coronaviruses in migratory and non-migratory Australian wild birds. Sci Rep. 2018;8(1):5980.

5. Peiris JSM, Lai ST, Poon LLM, Guan Y, Yam LYC, Lim W, et al. Coronavirus as a possible cause of severe acute respiratory syndrome. Lancet. 2003;361(9366):1319-25.

6. Casais R, Thiel V, Siddell SG, Cavanagh D, Britton P. Reverse genetics system for the avian coronavirus infectious bronchitis virus. J Virol. 2001;75(24):12359-69.
7. Wurm T, Chen H, Hodgson T, Britton P, Brooks G, Hiscox JA. Localization to the nucleolus is a common feature of coronavirus nucleoproteins, and the protein may disrupt host cell division. $\mathrm{J}$ Virol. 2001;75(19):9345-56.

8. Vijgen L, Keyaerts E, Lemey P, Moes E, Li S, Vandamme AM, et al. Circulation of genetically distinct contemporary human coronavirus OC43 strains. Virology. 2005;337(1):85-92.

9. Pratelli A, Martella V, Decaro N, Tinelli A, Camero M, Cirone F, et al. Genetic diversity of a canine coronavirus detected in pups with diarrhoea in Italy. J Virol Methods. 2003;110(1):9-17.

10. Marra MA, Jones SJ, Astell CR, Holt RA, Brooks-Wilson A, Butterfield YS, et al. The genome sequence of the SARSassociated coronavirus. Science. 2003;300(5624):1399-404.

11. Snijder EJ, Bredenbeek PJ, Dobbe JC, Thiel V, Ziebuhr J, Poon LL, et al. Unique and conserved features of genome and proteome of SARS-coronavirus, an early split-off from the coronavirus group 2 lineage. J Mol Biol. 2003;331(5):991-1004.

12. van der Hoek L, Pyrc K, Jebbink MF, Vermeulen-Oost W, Berkhout RJ, Wolthers KC, et al. Identification of a new human coronavirus. Nat Med. 2004;10(4):368-73.

13. Ksiazek TG, Erdman D, Goldsmith CS, Zaki SR, Peret T, Emery $\mathrm{S}$, et al. A novel coronavirus associated with severe acute respiratory syndrome. N Engl J Med. 2003;348(20):1953-66.

14. Zeng F, Chow KY, Leung FC. Estimated timing of the last common ancestor of the SARS coronavirus. N Engl J Med. 2003;349(25):2469-70.

15. Li X, Geng M, Peng Y, Meng L, Lu S. Molecular immune pathogenesis and diagnosis of COVID-19. J Pharm Anal. 2020;10(2): $102-8$.

16. Loeffelholz MJ, Tang YW. Laboratory diagnosis of emerging human coronavirus infections - the state of the art. Emerg Microbes Infect. 2020;9(1):747-56.

17. Udugama B, Kadhiresan P, Kozlowski HN, Malekjahani A, Osborne M, Li VYC, et al. Diagnosing COVID-19: the disease and tools for detection. ACS Nano. 2020;14(4):3822-35.

18. Zhang N, Wang L, Deng X, Liang R, Su M, He C, et al. Recent advances in the detection of respiratory virus infection in humans. J Med Virol. 2020;92(4):408-17.

19. Morales-Narváez E, Dincer C. The impact of biosensing in a pandemic outbreak: COVID-19. Biosens Bioelectron. 2020;112274.

20. Viruses ICoTo. A list of naturally occurring coronaviruses for which a complete genome sequence is available. In: Sequences CCG, editor. 2019.

21. Lu R, Zhao X, Li J, Niu P, Yang B, Wu H, et al. Genomic characterisation and epidemiology of 2019 novel coronavirus: implications for virus origins and receptor binding. Lancet. 2020;395(10224):565-74.

22. Su S, Wong G, Shi W, Liu J, Lai ACK, Zhou J, et al. Epidemiology, genetic recombination, and pathogenesis of coronaviruses. Trends Microbiol. 2016;24(6):490-502.

23. Khurshid Z, Asiri FYI, Al Wadaani H. Human saliva: noninvasive fluid for detecting novel coronavirus (2019-nCoV). Int J Environ Res Public Health 2020;17(7):2225.

24. Subbarao K, Roberts A. Is there an ideal animal model for SARS? Trends iMicrobiol. 2006;14(7):299-303.

25. Rota PA, Oberste MS, Monroe SS, Nix WA, Campagnoli R, Icenogle JP, et al. Characterization of a novel coronavirus associated with severe acute respiratory syndrome. Science. 2003;300(5624):1394-9.

26. Alsolamy S, Arabi YM. Infection with Middle East respiratory syndrome coronavirus. Can J Respir Ther. 2015;51(4):102.

27. Woodley M. How does coronavirus compare with previous global outbreaks?. newsGP. 2020.

28. Kim DD, Goel A. Estimating case fatality rates of COVID-19. Lancet Infect Dis. 2020;20(7):773-4. 
29. Gross R, Conzelmann C, Muller JA, Stenger S, Steinhart K, Kirchhoff F, et al. Detection of SARS-CoV-2 in human breastmilk. Lancet. 2020;395(10239):1757-8.

30. Masters PS. The molecular biology of coronaviruses. Adv Virus Res. 2006;66:193-292.

31. Ziegler C, Allon SJ, Nyquist SK, Mbano I, Miao VN, Cao Y, et al. SARS-CoV-2 receptor ACE2 is an interferon-stimulated gene in human airway epithelial cells and is enriched in specific cell subsets across tissues. Cell. 2020;181(5):1016-35.

32. Li F. Structure, function, and evolution of coronavirus spike proteins. Annu Rev Virol. 2016;3(1):237-61.

33. Kirchdoerfer RN, Cottrell CA, Wang N, Pallesen J, Yassine HM, Turner HL, et al. Pre-fusion structure of a human coronavirus spike protein. Nature. 2016;531(7592):118-21.

34. Tai W, He L, Zhang X, Pu J, Voronin D, Jiang S, et al. Characterization of the receptor-binding domain (RBD) of 2019 novel coronavirus: implication for development of RBD protein as a viral attachment inhibitor and vaccine. Cell Mol Immunol. 2020;17(6):613-20.

35. Hsin WC, Chang CH, Chang CY, Peng WH, Chien CL, Chang MF, et al. Nucleocapsid protein-dependent assembly of the RNA packaging signal of Middle East respiratory syndrome coronavirus. J Biomed Sci. 2018;25(1):47.

36. McBride R, van Zyl M, Fielding BC. The coronavirus nucleocapsid is a multifunctional protein. Viruses. 2014;6(8):2991-3018.

37. Chang CK, Hou MH, Chang CF, Hsiao CD, Huang TH. The SARS coronavirus nucleocapsid protein-forms and functions. Antivir Res. 2014;103:39-50.

38. Zuwala K, Golda A, Kabala W, Burmistrz M, Zdzalik M, Nowak $\mathrm{P}$, et al. The nucleocapsid protein of human coronavirus NL63. PLoS One. 2015;10(2):e0117833.

39. Fung TS, Liu DX. Post-translational modifications of coronavirus proteins: roles and function. Futur Virol. 2018;13(6):405-30.

40. Cong Y, Kriegenburg F, de Haan CAM, Reggiori F. Coronavirus nucleocapsid proteins assemble constitutively in high molecular oligomers. Sci Rep. 2017;7(1):5740.

41. Siu YL, Teoh KT, Lo J, Chan CM, Kien F, Escriou N, et al. The $\mathrm{M}, \mathrm{E}$, and $\mathrm{N}$ structural proteins of the severe acute respiratory syndrome coronavirus are required for efficient assembly, trafficking, and release of virus-like particles. J Virol. 2008;82(22): 11318-30.

42. Neuman BW, Kiss G, Kunding AH, Bhella D, Baksh MF, Connelly $\mathrm{S}$, et al. A structural analysis of $\mathrm{M}$ protein in coronavirus assembly and morphology. J Struct Biol. 2011;174(1):11-22.

43. De Haan C, Vennema H, Rottier P. Coronavirus envelope assembly is sensitive to changes in the terminal regions of the viral $\mathrm{M}$ protein. Coronaviruses and Arteriviruses: Springer; 1998. p. 367375 .

44. Schoeman D, Fielding BC. Coronavirus envelope protein: current knowledge. Virol J. 2019;16(1):69.

45. Ruch TR, Machamer CE. The coronavirus E protein: assembly and beyond. Viruses. 2012;4(3):363-82.

46. Ghosh A, Pithadia AS, Bhat J, Bera S, Midya A, Fierke CA, et al Self-assembly of a nine-residue amyloid-forming peptide fragment of SARS corona virus E-protein: mechanism of self aggregation and amyloid-inhibition of hIAPP. Biochemistry. 2015;54(13):2249-61.

47. Ghosh A, Bhattacharyya D, Bhunia A. Structural insights of a selfassembling 9-residue peptide from the C-terminal tail of the SARS corona virus E-protein in DPC and SDS micelles: a combined high and low resolution spectroscopic study. Biochim Biophys Acta Biomembr. 2018;1860(2):335-46.

48. Bai Y, Yao L, Wei T, Tian F, Jin DY, Chen L, et al. Presumed asymptomatic carrier transmission of COVID-19. JAMA. 2020;323(14):1406-7.
49. Lam TT-Y, Shum MH-H, Zhu H-C, Tong Y-G, Ni X-B, Liao Y$\mathrm{S}$, et al. Identifying SARS-CoV-2-related coronaviruses in Malayan pangolins. Nature. 2020;583:282-5.

50. Ji W, Wang W, Zhao X, Zai J, Li X. Homologous recombination within the spike glycoprotein of the newly identified coronavirus may boost cross-species transmission from snake to human. J Med Virol. 2020; 92(4):433-40.

51. Yang N, Che S, Zhang J, Wang X, Tang Y, Wang J, et al. Breastfeeding of infants born to mothers with COVID-19: a rapid review. Ann Transl Med. 2020;8(10):618.

52. Lackey KA, Pace RM, Williams JE, Bode L, Donovan SM, Järvinen KM, et al. SARS-CoV-2 and human milk: what is the evidence? Maternal Child Nutrition. 2020:e13032.

53. To KK, Tsang OT, Yip CC, Chan KH, Wu TC, Chan JM, et al. Consistent detection of 2019 novel coronavirus in saliva. Clin Infect Dis. 2020;71(15):841-3.

54. Guo L, Ren L, Yang S, Xiao M, Chang, Yang F, et al. Profiling early humoral response to diagnose novel coronavirus disease (COVID-19). Clin Infect Dis 2020;71(15):778-785.

55. Pan Y, Guan H, Zhou S, Wang Y, Li Q, Zhu T, et al. Initial CT findings and temporal changes in patients with the novel coronavirus pneumonia (2019-nCoV): a study of 63 patients in Wuhan, China. Eur Radiol. 2020;30(6):3306-9.

56. Ahmed W, Angel N, Edson J, Bibby K, Bivins A, O’Brien JW, et al. First confirmed detection of SARS-CoV-2 in untreated wastewater in Australia: a proof of concept for the wastewater surveillance of COVID-19 in the community. Sci Total Environ. 2020;728:138764.

57. Wang C, Horby PW, Hayden FG, Gao GF. A novel coronavirus outbreak of global health concern. Lancet. 2020;395(10223):470 3.

58. Liu R, Fu A, Deng Z, Li Y, Liu T. Promising methods for detection of novel coronavirus SARS-CoV-2. View. 2020;1(1):e4.

59. Mohamed E-T, Haim HB, Jinzhao S. A single and two-stage, closed-tube, molecular test for the 2019 novel coronavirus (COVID-19) at home, clinic, and points of entry. ChemRxiv. 2020. https://doi.org/10.26434/chemrxiv.11860137.

60. Paraskevis D, Kostaki EG, Magiorkinis G, Panayiotakopoulos G, Sourvinos G, Tsiodras S. Full-genome evolutionary analysis of the novel corona virus (2019-nCoV) rejects the hypothesis of emergence as a result of a recent recombination event. Infect Genet Evol. 2020;79:104212.

61. Behrmann O, Bachmann I, Spiegel M, Schramm M, El Wahed AA, Dobler G, et al. Rapid detection of SARS-CoV-2 by low volume real-time single tube reverse transcription recombinase polymerase amplification using an exo probe with an internally linked quencher (exo-IQ). Clin Chem. 2020;66(8):1047-54.

62. Shen M, Zhou Y, Ye J, Abdullah Al-Maskri AA, Kang Y, Zeng S, et al. Recent advances and perspectives of nucleic acid detection for coronavirus. J Pharm Anal. 2020;10(2):97-101.

63. Heid CA, Stevens J, Livak KJ, Williams PM. Real time quantitative PCR. Genome Res. 1996;6(10):986-94.

64. Stephensen CB, Casebolt DB, Gangopadhyay NN. Phylogenetic analysis of a highly conserved region of the polymerase gene from 11 coronaviruses and development of a consensus polymerase chain reaction assay. Virus Res. 1999;60(2):181-9.

65. Myint S, Johnston S, Sanderson G, Simpson H. Evaluation of nested polymerase chain methods for the detection of human coronaviruses 229E and OC43. Mol Cell Probes. 1994;8(5): 357-64.

66. Chu DKW, Pan Y, Cheng SMS, Hui KPY, Krishnan P, Liu Y, et al. Molecular diagnosis of a novel coronavirus (2019-nCoV) causing an outbreak of pneumonia. Clin Chem. 2020;66(4):549 55 .

67. Valasek MA, Repa JJ. The power of real-time PCR. Adv Physiol Educ. 2005;29(3):151-9. 
68. van Elden LJ, van Loon AM, van Alphen F, Hendriksen KA, Hoepelman AI, van Kraaij MG, et al. Frequent detection of human coronaviruses in clinical specimens from patients with respiratory tract infection by use of a novel real-time reverse-transcriptase polymerase chain reaction. J Infect Dis. 2004;189(4):652-7.

69. Hietala SK, Crossley BM. Armored RNA as virus surrogate in a real-time reverse transcriptase PCR assay proficiency panel. J Clin Microbiol. 2006;44(1):67-70.

70. Lin C, Xiang J, Yan M, Li H, Huang S, Shen C. Comparison of throat swabs and sputum specimens for viral nucleic acid detection in 52 cases of novel coronavirus (SARS-Cov-2)-infected pneumonia (COVID-19). Clin Chem Lab Med. 2020;58(7):1089-94.

71. Zhu X, Wang X, Han L, Chen T, Wang L, Li H, et al. Reverse transcription loop-mediated isothermal amplification combined with nanoparticles-based biosensor for diagnosis of COVID-19. medRxiv. 2020:2020.03.17.20037796.

72. Zhou P, Yang XL, Wang XG, Hu B, Zhang L, Zhang W, et al. A pneumonia outbreak associated with a new coronavirus of probable bat origin. Nature. 2020;579(7798):270-3.

73. Lu X, Whitaker B, Sakthivel SK, Kamili S, Rose LE, Lowe L, et al. Real-time reverse transcription-PCR assay panel for Middle East respiratory syndrome coronavirus. J Clin Microbiol. 2014;52(1):67-75.

74. Corman VM, Eckerle I, Bleicker T, Zaki A, Landt O, EschbachBludau M, et al. Detection of a novel human coronavirus by realtime reverse-transcription polymerase chain reaction. Euro Surveill. 2012;17(39):20285.

75. CDC 2019-Novel Coronavirus (2019-nCoV) Real-Time RT-PCR Diagnostic Panel. In: Prevention CfDCa, editor. 2020.

76. Wu Z, McGoogan JM. Characteristics of and important lessons from the coronavirus disease 2019 (COVID-19) outbreak in China: summary of a report of 72314 cases from the Chinese Center for Disease Control and Prevention. JAMA. 2020;323(13):1239-42.

77. Sheridan C. Coronavirus and the race to distribute reliable diagnostics. Nat Biotechnol. 2020;38(4):382-4.

78. Feng H, Liu Y, Lv M, Zhong J. A case report of COVID-19 with false negative RT-PCR test: necessity of chest CT. Jpn J Radiol. 2020;38(5):409-10.

79. Adachi D, Johnson G, Draker R, Ayers M, Mazzulli T, Talbot PJ, et al. Comprehensive detection and identification of human coronaviruses, including the SARS-associated coronavirus, with a single RT-PCR assay. J Virol Methods. 2004;122(1):29-36.

80. Setianingsih TY, Wiyatno A, Hartono TS, Hindawati E, Rosamarlina DAK, et al. Detection of multiple viral sequences in the respiratory tract samples of suspected Middle East respiratory syndrome coronavirus patients in Jakarta, Indonesia 20152016. Int J Infect Dis. 2019;86:102-7.

81. Liu R, Liu X, Yuan L, Han H, Shereen MA, Zhen J, et al. Analysis of adjunctive serological detection to nucleic acid test for severe acute respiratory syndrome coronavirus 2 (SARS-CoV-2) infection diagnosis. Int Immunopharmacol. 2020;86:106746.

82. Zhang S, Su X, Wang J, Chen M, Li C, Li T, et al. Nucleic acid testing for coronavirus disease 2019: demand, research progression, and perspective. Crit Rev Anal Chem. 2020:1-12.

83. Suo T, Liu X, Feng J, Guo M, Hu W, Guo D, et al. ddPCR: a more accurate tool for SARS-CoV-2 detection in low viral load specimens. Emerg Microbes Infect. 2020;9(1):1259-68.

84. Kim JM, Chung YS, Jo HJ, Lee NJ, Kim MS, Woo SH, et al. Identification of coronavirus isolated from a patient in Korea with COVID-19. Osong Public Health Res Perspect. 2020;11(1):3-7.

85. Sah R, Rodriguez-Morales AJ, Jha R, Chu DKW, Gu H, Peiris M, et al. Complete genome sequence of a 2019 novel coronavirus (SARS-CoV-2) strain isolated in Nepal. Microbiol Resour Announc. 2020;9(11).
86. Ren LL, Wang YM, Wu ZQ, Xiang ZC, Guo L, Xu T, et al. Identification of a novel coronavirus causing severe pneumonia in human: a descriptive study. Chin Med J. 2020;133(9):1015-24.

87. Reuter JA, Spacek DV, Snyder MP. High-throughput sequencing technologies. Mol Cell. 2015;58(4):586-97.

88. Quick J, Grubaugh ND, Pullan ST, Claro IM, Smith AD, Gangavarapu K, et al. Multiplex PCR method for MinION and Illumina sequencing of Zika and other virus genomes directly from clinical samples. Nat Protoc. 2017;12(6):1261-76.

89. Maurier F, Beury D, Flechon L, Varre JS, Touzet H, Goffard A, et al. A complete protocol for whole-genome sequencing of virus from clinical samples: application to coronavirus OC43. Virology. 2019;531:141-8.

90. Di L, Fu Y, Sun Y, Li J, Liu L, Yao J, et al. RNA sequencing by direct tagmentation of RNA/DNA hybrids. Proc Natl Acad Sci U S A. 2020;117(6):2886-93.

91. Lam TT, Jia N, Zhang YW, Shum MH, Jiang JF, Zhu HC, et al. Identifying SARS-CoV-2-related coronaviruses in Malayan pangolins. Nature. 2020;583(7815):282-5.

92. Lu J, Cui J, Qian Z, Wang Y, Zhang H, Duan Y, et al. On the origin and continuing evolution of SARS-CoV-2. Natl Sci Rev. 2020;7(6):1012-23.

93. Fang B, Liu L, Yu X, Li X, Ye G, Xu J, et al. Genome-wide data inferring the evolution and population demography of the novel pneumonia coronavirus (SARS-CoV-2). bioRxiv. 2020: 2020.03.04.976662.

94. Ding X, Yin K, Li Z, Lalla RV, Ballesteros E, Sfeir MM, Liu C. Ultrasensitive and visual detection of SARS-CoV-2 using all-inone dual CRISPR-Cas12a assay. Nat Commun. 2020;11:4711.

95. Pyrc K, Milewska A, Potempa J. Development of loop-mediated isothermal amplification assay for detection of human coronavirus-NL63. J Virol Methods. 2011;175(1):133-6.

96. Hong TC, Mai QL, Cuong DV, Parida M, Minekawa H, Notomi $\mathrm{T}$, et al. Development and evaluation of a novel loop-mediated isothermal amplification method for rapid detection of severe acute respiratory syndrome coronavirus. J Clin Microbiol. 2004;42(5):1956-61.

97. Bhadra S, Jiang YS, Kumar MR, Johnson RF, Hensley LE, Ellington AD. Real-time sequence-validated loop-mediated isothermal amplification assays for detection of Middle East respiratory syndrome coronavirus (MERS-CoV). PLoS One. 2015;10(4):e0123126.

98. Jiang YS, Bhadra S, Li B, Wu YR, Milligan JN, Ellington AD. Robust strand exchange reactions for the sequence-specific, realtime detection of nucleic acid amplicons. Anal Chem. 2015;87(6): 3314-20.

99. Jiang YS, Stacy A, Whiteley M, Ellington AD, Bhadra S. Amplicon competition enables end-point quantitation of nucleic acids following isothermal amplification. Chembiochem. 2017;18(17):1692-5.

100. Huang T-T, Liu S-C, Huang C-H, Lin C-J, Huang S-T. An integrated real-time electrochemical LAMP device for pathogenic bacteria detection in food. Electroanalysis. 2018;30(10):2397404.

101. Shirato K, Yano T, Senba S, Akachi S, Kobayashi T, Nishinaka T, et al. Detection of Middle East respiratory syndrome coronavirus using reverse transcription loop-mediated isothermal amplification (RT-LAMP). Virol J. 2014;11(1):139.

102. Shirato K, Semba S, El-Kafrawy SA, Hassan AM, Tolah AM, Takayama I, et al. Development of fluorescent reverse transcription loop-mediated isothermal amplification (RT-LAMP) using quenching probes for the detection of the Middle East respiratory syndrome coronavirus. J Virol Methods. 2018;258:41-8.

103. Lamb LE, Bartolone SN, Ward E, Chancellor MB. Rapid detection of novel coronavirus (COVID19) by reverse transcription- 
loop-mediated isothermal amplification. Available at SSRN 3539654. 2020.

104. Miyamoto S, Sano S, Takahashi K, Jikihara T. Method for colorimetric detection of double-stranded nucleic acid using leuco triphenylmethane dyes. Anal Biochem. 2015;473:28-33.

105. Wright AV, Nunez JK, Doudna JA. Biology and applications of CRISPR systems: harnessing nature's toolbox for genome engineering. Cell. 2016;164(1-2):29-44.

106. Li Y, Li S, Wang J, Liu G. CRISPR/Cas systems towards nextgeneration biosensing. Trends Biotechnol. 2019;37(7):730-43.

107. Li Y, Liu L, Liu G. CRISPR/Cas multiplexed biosensing: a challenge or an insurmountable obstacle? Trends Biotechnol. 2019;37(8):792-5.

108. Broughton JP, Deng X, Yu G, Fasching CL, Servellita V, Singh J, et al. CRISPR-Cas12-based detection of SARS-CoV-2. Nat Biotechnol. 2020;38(7):870-4.

109. Abudayyeh OO, Gootenberg JS, Konermann S, Joung J, Slaymaker IM, Cox DB, et al. C2c2 is a single-component programmable RNA-guided RNA-targeting CRISPR effector. Science. 2016;353(6299):aaf5573.

110. Williams BO, Warman ML. CRISPR/CAS9 technologies. J Bone Miner Res. 2017;32(5):883-8.

111. Gootenberg JS, Abudayyeh OO, Lee JW, Essletzbichler P, Dy AJ, Joung J, et al. Nucleic acid detection with CRISPR-Cas13a/C2c2. Science. 2017;356(6336):438-42.

112. Lucia C, Federico P-B, Alejandra GC. An ultrasensitive, rapid, and portable coronavirus SARS-CoV-2 sequence detection method based on CRISPR-Cas12. bioRxiv. 2020:2020.02.29.971127.

113. Freije CA, Myhrvold C, Boehm CK, Lin AE, Welch NL, Carter A, et al. Programmable inhibition and detection of RNA viruses using Cas13. Mol Cell. 2019;76(5):826-37 e11.

114. DIAZYME. Why do we need antibody tests for covid-19 and how to interpret test results 2020 [Available from: http://www. diazyme.com/covid-19-antibody-tests.

115. Ou X, Liu Y, Lei X, Li P, Mi D, Ren L, et al. Characterization of spike glycoprotein of SARS-CoV-2 on virus entry and its immune cross-reactivity with SARS-CoV. Nat Commun. 2020;11(1): 1620.

116. Che XY, Qiu LW, Liao ZY, Wang YD, Wen K, Pan YX, et al. Antigenic cross-reactivity between severe acute respiratory syndrome-associated coronavirus and human coronaviruses 229E and OC43. J Infect Dis. 2005;191(12):2033-7.

117. Agnihothram S, Gopal R, Yount BL Jr, Donaldson EF, Menachery VD, Graham RL, et al. Evaluation of serologic and antigenic relationships between middle eastern respiratory syndrome coronavirus and other coronaviruses to develop vaccine platforms for the rapid response to emerging coronaviruses. J Infect Dis. 2014;209(7):995-1006.

118. Leung GM, Chung PH, Tsang T, Lim W, Chan SK, Chau P, et al. SARS-CoV antibody prevalence in all Hong Kong patient contacts. Emerg Infect Dis. 2004;10(9):1653-6.

119. Yan Y, Chang L, Wang L. Laboratory testing of SARS-CoV, MERS-CoV, and SARS-CoV-2 (2019-nCoV): current status, challenges, and countermeasures. Rev Med Virol. 2020;30(3): e2106.

120. Hashem AM, Al-Amri SS, Al-Subhi TL, Siddiq LA, Hassan AM, Alawi MM, et al. Development and validation of different indirect ELISAs for MERS-CoV serological testing. J Immunol Methods. 2019;466:41-6.

121. Buchholz U, Muller MA, Nitsche A, Sanewski A, Wevering N, Bauer-Balci T, et al. Contact investigation of a case of human novel coronavirus infection treated in a German hospital, October-November 2012. Euro Surveill. 2013;18(8).

122. Puzelli S, Azzi A, Santini M, Di Martino A, Facchini M, Castrucci $\mathrm{M}$, et al. Investigation of an imported case of Middle East respiratory syndrome coronavirus (MERS-CoV) infection in Florence, Italy, May to June 2013. Euro Surveill. 2013;18(34): 20564.

123. Baniukevic J, Kirlyte J, Ramanavicius A, Ramanaviciene A. Application of oriented and random antibody immobilization methods in immunosensor design. Sensors Actuators B Chem. 2013;189:217-23.

124. Makaraviciute A, Ruzgas T, Ramanavicius A, Ramanaviciene A. Antibody fragment immobilization on planar gold and gold nanoparticle modified quartz crystal microbalance with dissipation sensor surfaces for immunosensor applications. Anal Methods. 2014;6(7):2134-40.

125. Virzonis D, Vanagas G, Ramanaviciene A, Makaraviciute A, Barauskas D, Ramanavicius A, et al. Resonant gravimetric immunosensing based on capacitive micromachined ultrasound transducers. Microchim Acta. 2014;181(13-14):1749-57.

126. Ramanavicius A, Oztekin Y, Ramanaviciene A. Electrochemical formation of polypyrrole-based layer for immunosensor design. Sensors Actuators B Chem. 2014;197:237-43.

127. Viter R, Savchuk M, Starodub N, Balevicius Z, Tumenas S, Ramanaviciene A, et al. Photoluminescence immunosensor based on bovine leukemia virus proteins immobilized on the $\mathrm{ZnO}$ nanorods. Sensors Actuators B Chem. 2019;285:601-6.

128. Tereshchenko A, Smyntyna V, Ramanavicius A. Interaction mechanism between $\mathrm{TiO} 2$ nanostructures and bovine leukemia virus proteins in photoluminescence-based immunosensors. RSC Adv. 2018;8(66):37740-8.

129. Lu M, Liu Q, Wang X, Zhang J, Zhang X, Shi D, et al. Development of an indirect ELISA for detecting porcine deltacoronavirus IgA antibodies. Arch Virol. 2020;165(4):84551.

130. Su M, Li C, Guo D, Wei S, Wang X, Geng Y, et al. A recombinant nucleocapsid protein-based indirect enzyme-linked immunosorbent assay to detect antibodies against porcine deltacoronavirus. J Vet Med Sci. 2016;78(4):601-6.

131. Trivedi SU, Miao C, Sanchez JE, Caidi H, Tamin A, Haynes L, et al. Development and evaluation of a multiplexed immunoassay for simultaneous detection of serum IgG antibodies to six human coronaviruses. Sci Rep. 2019;9(1):1390.

132. Okba NMA, Muller MA, Li W, Wang C, GeurtsvanKessel CH, Corman VM, et al. SARS-CoV-2 specific antibody responses in COVID-19 patients. medRxiv. 2020:2020.03.18.20038059.

133. Khan S, Nakajima R, Jain A, de Assis RR, Jasinskas A, Obiero $\mathrm{JM}$, et al. Analysis of serologic cross-reactivity between common human coronaviruses and SARS-CoV-2 using coronavirus antigen microarray. bioRxiv. 2020:2020.03.24.006544.

134. Zhao R, Li M, Song H, Chen J, Ren W, Feng Y, et al. Early detection of SARS-CoV-2 antibodies in COVID-19 patients as a serologic marker of infection. Clin Infect Dis. 2020.

135. Liu L, Liu W, Zheng Y, Jiang X, Kou G, Ding J, et al. A preliminary study on serological assay for severe acute respiratory syndrome coronavirus 2 (SARS-CoV-2) in 238 admitted hospital patients. Microbes Infect. 2020;22(4-5):206-11.

136. He Y, Luo J, Yang J, Song J, Wei L, Ma W. Value of viral nucleic acid in sputum and feces and specific $\operatorname{IgM} / \operatorname{IgG}$ in serum for the diagnosis of coronavirus disease 2019. Front Cell Infect Microbiol. 2020;10(445):445.

137. Li Z, Yi Y, Luo X, Xiong N, Liu Y, Li S, et al. Development and clinical application of a rapid IgM-IgG combined antibody test for SARS-CoV-2 infection diagnosis. J Med Virol. 2020;n/a(n/a).

138. Broughton JP, Deng X, Yu G, Fasching CL, Singh J, Streithorst J, et al. Rapid detection of 2019 novel coronavirus SARS-CoV-2 using a CRISPR-based DETECTR lateral flow assay. medRxiv. 2020:2020.03.06.20032334. 
139. BioMedomics. COVID-19 IgM/IgG rapid test 2020 [Available from: https://www.biomedomics.com/products/infectiousdisease/covid-19-rt/.

140. Edwards A. COVID-19 tests: how they work and what's in development. In: Ketchell M, editor.: The CONVERSATION; 2020.

141. Becherer L, Borst N, Bakheit M, Frischmann S, Zengerle R, von Stetten F. Loop-mediated isothermal amplification (LAMP) - review and classification of methods for sequence-specific detection. Anal Methods. 2020;12(6):717-46.

142. Yin C. Genotyping coronavirus SARS-CoV-2: methods and implications. Genomics. 2020;112(5):3588-96.

143. Fallik D. How antibody tests work and could help fight the coronavirus. ScienceNews. 2020.

144. Wang Y, Wang Y, Chen Y, Qin Q. Unique epidemiological and clinical features of the emerging 2019 novel coronavirus pneumonia (COVID-19) implicate special control measures. J Med Virol. 2020;92(6):568-76.

145. GENEMEDI. Recombinant $2019 \mathrm{nCoV(SARS} 2$ coronavirus) antigens reagents 2019 [Available from: https://www.genemedi.net/ i/recombinant-2019-ncov-antigens-reagents.

146. Diao B, Wen K, Chen J, Liu Y, Yuan Z, Han C, et al. Diagnosis of acute respiratory syndrome coronavirus 2 infection by detection of nucleocapsid protein. medRxiv. 2020:2020.03.07.20032524.

147. Porte L, Legarraga P, Vollrath V, Aguilera X, Munita JM, Araos $\mathrm{R}$, et al. Evaluation of a novel antigen-based rapid detection test for the diagnosis of SARS-CoV-2 in respiratory samples. Int J Infect Dis. 2020;99:328-33.

148. Frazee BW, Rodriguez-Hoces de la Guardia A, Alter H, Chen CG, Fuentes EL, Holzer AK, et al. Accuracy and discomfort of different types of intranasal specimen collection methods for molecular influenza testing in emergency department patients. Ann Emerg Med 2018;71(4):509-517 e1.

149. Bruning AHL, Leeflang MMG, Vos J, Spijker R, de Jong MD, Wolthers KC, et al. Rapid tests for influenza, respiratory syncytial virus, and other respiratory viruses: a systematic review and metaanalysis. Clin Infect Dis. 2017;65(6):1026-32.

150. Pokhrel P, Hu C, Mao H. Detecting the coronavirus (COVID-19). ACS Sens. 2020;5(8):2283-96.

151. Subsoontorn P, Lohitnavy M, Kongkaew C. The diagnostic accuracy of nucleic acid point-of-care tests for human coronavirus: a systematic review and meta-analysis. medRxiv. 2020.

152. Seo G, Lee G, Kim MJ, Baek SH, Choi M, Ku KB, et al. Rapid detection of COVID-19 causative virus (SARS-CoV-2) in human nasopharyngeal swab specimens using field-effect transistorbased biosensor. ACS Nano. 2020;14(4):5135-42.

153. An J, Liao X, Xiao T, Qian S, Yuan J, Ye H, et al. Clinical characteristics of the recovered COVID-19 patients with re-detectable positive RNA test. medRxiv. 2020:2020.03.26.20044222.

154. Pan F, Ye T, Sun P, Gui S, Liang B, Li L, et al. Time course of lung changes at chest $\mathrm{CT}$ during recovery from coronavirus disease 2019 (COVID-19). Radiology. 2020;295(3):715-21.

155. Ding X, Xu J, Zhou J, Long Q. Chest CT findings of COVID-19 pneumonia by duration of symptoms. Eur J Radiol. 2020;127:109009.

156. Song J, Wang H, Liu Y, Wu W, Dai G, Wu Z, et al. End-to-end automatic differentiation of the coronavirus disease 2019
(COVID-19) from viral pneumonia based on chest CT. Eur J Nucl Med Mol Imaging. 2020;47(11):2516-24.

157. Wang W, Xu Y, Gao R, Lu R, Han K, Wu G, et al. Detection of SARS-CoV-2 in different types of clinical specimens. JAMA. 2020;323(18): 1843-4.

158. Qiu G, Gai Z, Tao Y, Schmitt J, Kullak-Ublick GA, Wang J. Dualfunctional plasmonic photothermal biosensors for highly accurate severe acute respiratory syndrome coronavirus 2 detection. ACS Nano. 2020;14(5):5268-77.

159. Pan Y, Long L, Zhang D, Yuan T, Cui S, Yang P, et al. Potential false-negative nucleic acid testing results for severe acute respiratory syndrome coronavirus 2 from thermal inactivation of samples with low viral loads. Clin Chem. 2020;66(6):794-801.

160. Ng M-Y, Lee EYP, Yang J, Yang F, Li X, Wang H, et al. Imaging profile of the COVID-19 infection: radiologic findings and literature review. Radiology: Cardiothoracic Imaging. 2020;2(1): e200034.

161. Pan F, Ye T, Sun P, Gui S, Liang B, Li L, et al. Time course of lung changes on chest CT during recovery from 2019 novel coronavirus (COVID-19) pneumonia. Radiology. 2020:200370.

162. Narin A, Kaya C, Pamuk Z. Automatic detection of coronavirus disease (covid-19) using $\mathrm{x}$-ray images and deep convolutional neural networks. arXiv preprint arXiv:200310849. 2020.

163. Corman VM, Landt O, Kaiser M, Molenkamp R, Meijer A, Chu DK, et al. Detection of 2019 novel coronavirus (2019-nCoV) by real-time RT-PCR. Euro Surveill. 2020;25(3).

164. Salehi S, Abedi A, Balakrishnan S, Gholamrezanezhad A. Coronavirus disease 2019 (COVID-19): a systematic review of imaging findings in 919 patients. AJR Am J Roentgenol. 2020;215(1):87-93

165. Xie X, Zhong Z, Zhao W, Zheng C, Wang F, Liu J. Chest CT for typical 2019-nCoV pneumonia: relationship to negative RT-PCR testing. Radiology. 2020:200343.

166. Deepak S, Kottapalli K, Rakwal R, Oros G, Rangappa K, Iwahashi $\mathrm{H}$, et al. Real-time PCR: revolutionizing detection and expression analysis of genes. Curr Genomics. 2007;8(4):234-51.

167. Jawerth N. How is the COVID-19 virus detected using real time RT-PCR?: International Atomic Energy Agency; 2020.

168. Nishiura H, Kobayashi T, Miyama T, Suzuki A, Jung SM, Hayashi $\mathrm{K}$, et al. Estimation of the asymptomatic ratio of novel coronavirus infections (COVID-19). Int J Infect Dis. 2020;94: $154-5$.

169. Hu R, Sun X, Liu C, Li G. Detection of nucleic acid and antibody of new coronavirus. J Clinic Exper Cosme Derma 3: 010. Henry Publishing Groups Hu R; 2020.

170. Fozouni P, Son S, Díaz de León Derby M, Knott GJ, Gray CN, D'Ambrosio MV, et al. Direct detection of SARS-CoV-2 using CRISPR-Cas 13a and a mobile phone. medRxiv. 2020: 2020.09.28.20201947.

Publisher's note Springer Nature remains neutral with regard to jurisdictional claims in published maps and institutional affiliations. 